\title{
Impact of Organic Amendment with Alternate Wetting and Drying Irrigation on Rice Yield, Water Use Efficiency and Physicochemical Properties of Soil
}

\author{
Ahmad Numery Ashfaqul Haque 1,2 (D), Md Kamal Uddin 1,*(D), Muhammad Firdaus Sulaiman ${ }^{1}$ (D), \\ Adibah Mohd Amin ${ }^{1}$, Mahmud Hossain ${ }^{3}$ (D), Azharuddin Abd Aziz ${ }^{4}$ and Mehnaz Mosharrof ${ }^{1}$ \\ 1 Department of Land Management, Faculty of Agriculture, Universiti Putra Malaysia, \\ Serdang 43400, Malaysia; numerybau@gmail.com (A.N.A.H.); muhdfirdaus@upm.edu.my (M.F.S.); \\ adibahamin@upm.edu.my (A.M.A.); mmd.mehnaz@gmail.com (M.M.) \\ 2 Bangladesh Institute of Nuclear Agriculture (BINA), Mymensingh 2202, Bangladesh \\ 3 Department of Soil Science, Bangladesh Agricultural University, Mymensingh 2202, Bangladesh; \\ mahmud.ss@bau.edu.bd \\ 4 Research and Instrumentation Section, Department of Chemistry Malaysia, Jalan Sultan, \\ Petaling Jaya 46661, Malaysia; azharuddin@kimia.gov.my \\ * Correspondence: mkuddin07@gmail.com
}

Citation: Haque, A.N.A.; Uddin, M.K.; Sulaiman, M.F.; Amin, A.M.; Hossain, M.; Aziz, A.A.; Mosharrof M. Impact of Organic Amendment with Alternate Wetting and Drying Irrigation on Rice Yield, Water Use Efficiency and Physicochemical Properties of Soil. Agronomy 2021, 11, 1529. https://doi.org/10.3390/ agronomy11081529

Academic Editors: Evan A. N. Marks and Xavier Domene

Received: 12 June 2021

Accepted: 26 July 2021

Published: 30 July 2021

Publisher's Note: MDPI stays neutral with regard to jurisdictional claims in published maps and institutional affiliations.

Copyright: (c) 2021 by the authors. Licensee MDPI, Basel, Switzerland. This article is an open access article distributed under the terms and conditions of the Creative Commons Attribution (CC BY) license (https:/ / creativecommons.org/licenses/by/ $4.0 /)$.

\begin{abstract}
A pot experiment was executed to investigate the impact of biochar and compost with water-saving irrigation on the rice yield, water use efficiency, and physicochemical properties of soil. Two irrigation regimes-namely alternate wetting and drying (AWD) and continuous flooding (CF) - and four types of organic amendments (OA) - namely rice husk biochar (RHB), oil palm empty fruit bunch biochar (EFBB), compost and a control-were applied to evaluate their effects. Under the AWD irrigation regime, the maximum grain was produced by RHB ( $241.12 \mathrm{~g})$, whereas under the same organic amendments, both AWD and CF produced a similar grain yield. Under the same organic amendment, a significantly higher water use efficiency (WUE) was observed from the AWD irrigation with RHB $\left(6.30 \mathrm{~g} \mathrm{~L}^{-1}\right)$ and EFBB $\left(5.80 \mathrm{~g} \mathrm{~L}^{-1}\right)$. Within the same irrigation regime, soil $\mathrm{pH}$, cation exchange capacity, total carbon, total nitrogen and available phosphorus were enhanced due to the incorporation of biochar and compost, while higher soil exchangeable potassium was observed under CF irrigation for all treatments. RHB and EFBB significantly reduced the soil bulk density (up to $20.70 \%$ ) and increased porosity (up to $16.70 \%$ ) under both irrigation regimes. The results imply that the use of biochar with AWD irrigation could enhance the nutrient uptake and physicochemical properties of soil and allow rice to produce a greater yield with less water consumption.
\end{abstract}

Keywords: rice; intermittent irrigation; biochar; water use efficiency; soil physicochemical properties

\section{Introduction}

Rice (Oryza sativa L.) is a major staple food for half of the world's population, the majority of whom live in developing nations, and rice requires up about $11 \%$ of the world's agricultural land and is positioned second in terms of area coverage [1]. Rice is the world's most water-intensive crop, using between $34 \%$ and $43 \%$ of total irrigation water [2]. According to a recent estimate for irrigated rice cultivation, about $2500 \mathrm{~L}$ of water is required to produce $1 \mathrm{~kg}$ of rice; in contrast, barley or wheat needs 500 to $1000 \mathrm{~L}$ of irrigation water to produce the same amount of grain [3]. Due to high population growth, expanding urbanization and industrialization, resource depletion and environmental pollution have resulted in limited sources for irrigation water [4,5]. Under this increasing global situation of water crisis, several serious challenges are facing global agriculture in the attempt to provide sufficient food for the growing population [6].

Many alternative cropping practices (aerobic rice, direct seeding) have been practiced to cope with the global water crisis. Alternate wetting and drying (AWD) is also an efficient 
approach to save irrigation water for sustainable rice production by the periodic drying and flooding of rice fields [7]. In the AWD irrigation system, after the flooding of the field, the water levels decrease gradually, and when this level drops beneath $15 \mathrm{~cm}$ from the soil surface, the field is re-flooded to a $5 \mathrm{~cm}$ ponding water depth [7]. A perforated pipe is used to monitor the water level below the soil surface. AWD can reduce $15 \%$ to $30 \%$ of irrigation water compared to conventional flooded rice systems [8]. Depending on the soil type and hydrological conditions, the efficiency of AWD can fluctuate significantly, causing an economic yield loss for rice [9]. Moreover, during dry cycles, plants uptake lower amounts of nutrients due to the moisture stress condition compared to traditional flooded rice and ultimately reduce water productivity $[8,10]$. The water-saving effectiveness of AWD may be overlooked by potential yield loss. To cope with these drawbacks of AWD, the incorporation of organic amendments in the soil has a great potential for improving soil physicochemical properties and moisture retention.

In the context of climatic changes, such as droughts, severe rainstorms, floods, and extreme temperatures, agricultural soil ecosystem services are becoming increasingly important [11]. Biochar application in the agricultural field has become a research hotspot in the last decade for long-term soil fertility enhancement $[12,13]$. It is a carbonaceous material produced by heating plant or animal residue at comparatively low temperatures under oxygen-limited conditions, and the obtained product is now widely used as an organic amendment [14]. Biochar application positively influences the soil ecosystem by carbon sequestration and nutrient cycling, improving soil biological activity and boosting the capacity of soil to retain more moisture under dry conditions [15].

Biochar inclusion not only adds nutrients but also improves soil fertility by increasing the nutrient availability [16]. Biochar improves soil organic matter status, increasing carbon content while also adding nutrients, such as nitrogen, potassium, phosphorus and magnesium $[17,18]$. Biochar also improves soil physical properties, such as aggregation, porosity and bulk density and hydrological properties, such as available water capacity, water holding capacity, infiltration, etc. [19-21]. In Malaysia, rice processing industries and oil palm extracting factories produce a large amount of rice husks and empty fruit bunches, respectively, and the conversion of these by-products into biochar has great potential to be used as an organic amendment. Furthermore, compost is one of the most widely used organic amendments around the world due to its beneficial effect on soil physicochemical properties. Soil loses organic substances in various ways, but the incorporation of compost acts as an external source of soil organic matter that minimizes nutrient loss and thereby maintains soil fertility [22]. Compost is enriched with different plant nutrients, and the inclusion of compost in the soil increases the cation exchange capacity and reduces nutrient leaching into sub-soil [23]. The incorporation of compost decreases bulk density, enhances porosity and improves soil water retention properties, such ashydraulic conductivity, plant available water, and water content, as reported by Kranz et al. [24].

Generally, there are two types of paddy produced in Malaysia: Peninsular Malaysia is covered by wetland paddy and Sabah and Sarawak by upland paddy [25]. For rice production, Malaysia still relies on irrigated wetland rice; although the yield of wetland rice is higher, it requires a large amount of water to keep the land in flooded conditions [26]. Of the total rice-producing area, around $88 \%(69,238 \mathrm{ha})$ comprises irrigated lowland paddy fields situated in Peninsular Malaysia [27]. Malaysia commonly practices continuous flooding for conventional irrigated wetland rice production, which requires a large quantity of water, which at present is essential to promote AWD for sustainable technology to enhance water use efficiency. Although AWD causes some hindrance to soil physicochemical properties, replenishing these properties usingbiochar and/or compost incorporation in soil is the main challenge of this study. The management of organic amendments, such as biochar and compost in AWD water-saving irrigation practice to maintain soil physicochemical properties for sustainable rice production with better environmental quality is the new contribution of this research. 
Thus, we hypothesized that the application of selected organic amendments-i.e., biochars (RHB and EFBB) and compost-may improve the growth and yield of rice, consecutively enhancing the physicochemical properties of soil under AWD irrigation. A pot experiment was carried out to test these hypotheses. Therefore, the objective of the study was to study the response of rice influenced by biochar and compost under water-saving irrigation (AWD); furthermore, we aimed to investigate the effect of biochar and compost on the physicochemical properties of soil under AWD irrigation.

\section{Material and Methods}

\subsection{Soil, Biochar and Compost Collection and Characterization}

The experimental soil was collected from a $0-20 \mathrm{~cm}$ depth of a wetland rice field located in TanjungKarang $\left(3^{\circ} 28.2730^{\prime} \mathrm{N}\right.$ latitude and $101^{\circ} 8.7050^{\prime} \mathrm{E}$ longitude) area within the Kuala Selangor district of Selangor state in Peninsular Malaysia. Standard procedures were used to characterize a composite soil sample that had been air dried, pulverized and sieved through a $2 \mathrm{~mm}$ mesh.

The pipette method was used to determine the soil textural class [28]. A digital $\mathrm{pH}$ meter was used to measure the $\mathrm{pH}$ of the soil (soil and distilled water at the ratio of 1:2.5) [29]. The total carbon and nitrogen in soil were measured using a CNS analyzer (LECO, Corporation, Saint Joseph, MI, USA). Available phosphorus in soil was determined by the method described by Bray and Kurtz [30]. The cation exchange capacity (CEC) and exchangeable cations, such as potassium $\left(\mathrm{K}^{+}\right)$, calcium $\left(\mathrm{Ca}^{2+}\right)$ and magnesium $\left(\mathrm{Mg}^{2+}\right)$ were determined using the ammonium acetate $\left(\mathrm{NH}_{4} \mathrm{OAc}\right)$ leaching method [31] and analyzed using an atomic absorption spectrophotometer (AAS). Appendix A (Table A1) presents the initial soil properties.

In this study, three types of organic amendments were used: compost, rice husk biochar and oil palm empty fruit bunch biochar. All of the organic materials were supplied from a commercial establishment. Rice husk and empty fruit bunches of oil palm were pyrolyzed at $300{ }^{\circ} \mathrm{C}$ and $450{ }^{\circ} \mathrm{C}$, respectively, to obtain biochars. The $\mathrm{pH}$ of organic amendments was estimated by a 1:10 ratio $(w / w)$ of solid and water and CEC by the ammonium acetate $\left(\mathrm{NH}_{4} \mathrm{OAc}\right)$ leaching method [29]. Total carbon, nitrogen and sulfur contents in biochar and compost were determined by a CNS analyzer. Other nutrient contents-i.e., total $\mathrm{P}, \mathrm{K}, \mathrm{Ca}$ and $\mathrm{Mg}$, etc.-were analyzed by dry ashing [32] followed by the use of an atomic absorption spectrophotometer (AAS, PerkinElmer Analyst 400, Waltham, MA, USA). The chemical properties of biochar and compost are presented in Appendix A (Table A2).

\subsection{Experimental Site and Pot Experiment}

A glasshouse experiment was carried out at the experimental field of the Agriculture faculty, University Putra Malaysia (UPM), Serdang, Selangor, Malaysia from January to April 2020. The field is located at $3^{\circ} 00^{\prime} \mathrm{N}$ and $101^{\circ} 71^{\prime} \mathrm{E}$ with an elevation of about $56.8 \mathrm{~m}$ above sea level. The monthly weather data during the study period are presented in Appendix A (Table A3). The experiment was laid out in a factorial randomized complete block design (RCBD) with four replications. The first factor was two irrigation regimes-(i) alternate wetting and drying (AWD), (ii) continuous flooding (CF) - and the second factor was organic amendments (OA) - (i) rice husk biochar (RHB), (ii) oil palm empty fruit bunch biochar (EFBB), (iii) compost, (iv) control (no organic amendments). The rice variety used in this study was MR297 developed by the Malaysian Agricultural Research and Development Institute (MARDI).

A total of 32 experimental pots ( $45 \mathrm{~cm}$ in diameter and $52 \mathrm{~cm}$ in height) were filled with $50 \mathrm{~kg}$ of air-dried soil; furthermore, for the AWD irrigation regime (16 pots), a $4 \mathrm{~cm}$ diameter and $30 \mathrm{~cm}$ long perforated PVC pipe was inserted in soil up to $20 \mathrm{~cm}$ deep by remaining $10 \mathrm{~cm}$ above the surface. Other pots were kept normal. There was no perforation at the end of the experimental pot to avoid the percolation loss of water. After the pot setup, RHB, EFBB and compost at $4 \%$ of soil weight were applied separately while maintaining 
the control pot. The organic materials were mixed thoroughly with soil 10 days before the transplanting and irrigated for proper seedling establishment. Nitrogen $\left(121 \mathrm{~kg} \mathrm{ha}^{-1}\right)$, phosphorus $\left(29 \mathrm{~kg} \mathrm{ha}^{-1}\right)$ and potassium $\left(100 \mathrm{~kg} \mathrm{ha}^{-1}\right)$ were applied from urea, triple superphosphate and muriate of potash, respectively, as recommended by MARDI.

In each pot, four 20-day-old seedlings were transplanted by maintaining a $15 \mathrm{~cm}$ plantto-plant distance, and water levels were maintained at 3 to $5 \mathrm{~cm}$ until 15 days for seedling establishment. Moreover, water levels in the pots under AWD irrigation were monitored by a perforated PVC pipe and allowed to dry until the water levels reached $15 \mathrm{~cm}$ from the soil surface and then flooded to $5 \mathrm{~cm}$ above the surface (Figure 1). These intermittent drying cycles continued for the whole growth period except the flowering stage. However, water levels in the pot under continuous flooded irrigation were maintained at $3-5 \mathrm{~cm}$ from the soil surface. Weeding and spraying pesticides was done when necessary. After the full maturation, rice was harvested at 95 days after transplanting.
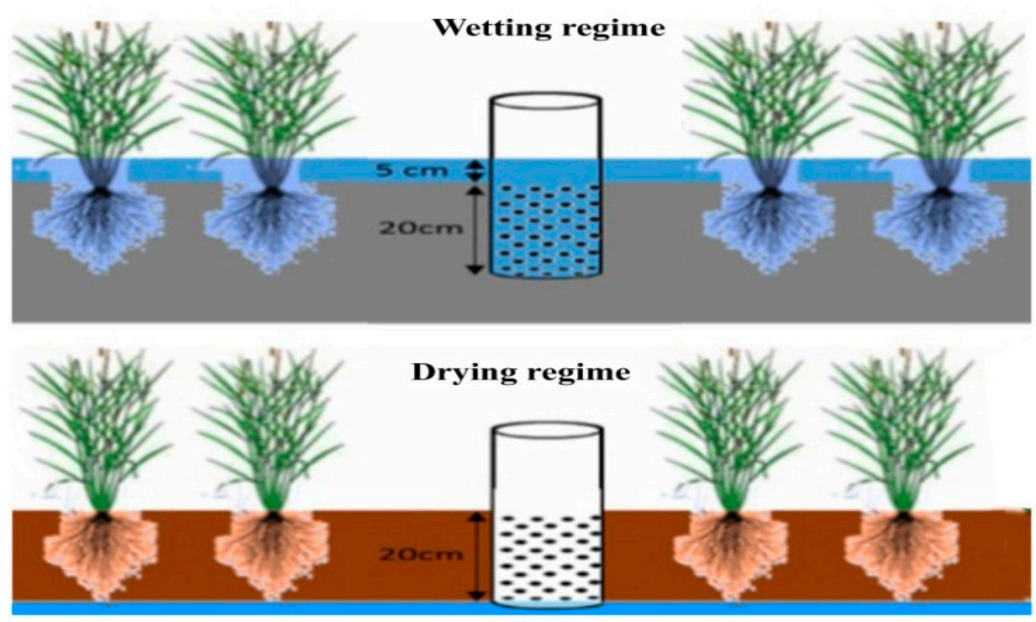

Figure 1. Wetting and drying regimes during the AWD irrigation.

\subsection{Data Collection}

\subsubsection{Growth and Yield of Rice}

The chlorophyll content of rice leaves was measured using a SPAD meter at the vegetative, flowering and mature stages (SPAD-502, Konica Minolta Sensing Inc. Sakai Osaka, Japan). Other yield components-i.e., plant height, numbers of tiller hill ${ }^{-1}$, panicle length and number of grains panicle ${ }^{-1}$-were recorded at harvest. After harvesting from each pot, grain and straw were separated and their weight was recorded. The biological yield of a pot corresponded to the summation of total grain and straw yield.

\subsubsection{Analysis of Nutrient Concentration in Plant Tissue}

After the harvesting of rice, grain and straw samples were collected from individual pots and kept in a paper bag separately. The paper bag with the sample was put into the oven for drying at $70{ }^{\circ} \mathrm{C}$ for $72 \mathrm{~h}$ until it reached a constant weight. After drying, the plant samples were crushed and sieved with a $4 \mathrm{~mm}$ sieve. Total $\mathrm{N}$ in plant tissue was determined using a CNS analyzer (LECO, Corporation, Saint Joseph, MI, USA); other total elements, such as $\mathrm{P}, \mathrm{K}, \mathrm{Ca}$, and $\mathrm{Mg}$ content were determined by dry ashing [32], and the concentrations of the elements in the solution from dry ashing were determined using an atomic absorption spectrophotometer (AAS, PerkinElmer Analyst 400, Waltham, MA, USA).

\subsubsection{Carbon Isotope Discrimination $\left(\Delta^{13} \mathrm{C} \%\right.$ ) in Leaf}

After recording the yield at harvest, representative rice leaves were sampled from each pot and washed with distilled water, followed by wiping adsorbed water with tissue 
paper, and were kept in the oven at $70{ }^{\circ} \mathrm{C}$ for $72 \mathrm{~h}$. Then, dried leaves were milled with a $2 \mathrm{~mm}$ sieve and then finely ground in a ball mill and weighed in tin capsules. The mass spectrometry of the $\mathrm{CO}_{2}$, generated from the combustion of sub-samples from each sample, was used to determine the isotopic carbon composition in the leaf samples. An elemental analyzer (EA) coupled to an isotope ratio mass spectrometer (IRMS) using wheat flour (Cat No: IA-R001) as a standard was used to determine the carbon isotope composition $\left(\delta^{13} \mathrm{C}\right)$ in leaf samples.

The carbon isotope discrimination $\left(\Delta^{13} \mathrm{C} \%\right.$ o $)$ in rice leaf was calculated from the following equation [33]:

$$
\text { Carbon isotope discrimination }\left(\Delta^{13} C \%\right)=\left[\left(\delta^{13} C_{a}-\delta^{13} C_{1}\right) /\left(1+\delta^{13} C_{1}\right)\right] \times 1000
$$

where $\delta^{13} C_{a}$ is assumed to be $\% \delta^{13} C$ of air $\left(-8 \%\right.$ ) and $\delta^{13} C_{1}$ denotes the $\% \delta^{13} C$ reading from the rice leaf.

2.3.4. Determination of Soil Moisture, Irrigation Water Volume and Water Use Efficiency (WUE)

At the end of each drying cycle of the AWD irrigation regime, before reflooding, the volumetric water content was measured by a Fieldscout TDR 150 soil moisture meter (USA).

The amount of total irrigation water (L) consumed by the rice in each plot was estimated by subtracting the water required for puddling before transplanting the seedlings from the total volume of water applied over the crop growing season. The volume of water during each irrigation was measured by a volumetric jar. To estimate the water use efficiency (WUE), the following equation was used [34]:

$$
\text { WUE }\left(\mathrm{g} \mathrm{L}^{-1}\right)=\frac{\text { Biological yield }(\mathrm{g})}{\text { Total water used }(\mathrm{L})}
$$

\subsubsection{Determination of Soil Physical Properties}

Soil physical properties, such as bulk density $\left(\mathrm{g} \mathrm{cm}^{-3}\right)$, particle density $\left(\mathrm{g} \mathrm{cm}^{-3}\right)$, and soil porosity (\%) were determined at the end of harvest. Bulk density was determined by core sampling from a 0-20 cm soil depth [28] and particle density was determined by the volumetric method [35] from the following equations:

$$
\begin{gathered}
\text { Bulk density }\left(\mathrm{g} \mathrm{cm}^{-3}\right)=\frac{\text { Weight of oven dry soil }(\mathrm{g})}{\text { Total volume of soil }\left(\mathrm{cm}^{3}\right)} \\
\text { Particle density }\left(\mathrm{g} \mathrm{cm}^{-3}\right)=\frac{\text { Weight of oven dry soil }(\mathrm{g})}{\text { Volume of soil solid }\left(\mathrm{cm}^{3}\right)}
\end{gathered}
$$

Total soil porosity was calculated using the bulk and particle density value from the following equation [28]:

$$
\text { Total soil porosity }(\%)=\left[1-\frac{\text { Bulk density }\left(\mathrm{g} \mathrm{cm}^{-3}\right)}{\text { Particle density }\left(\mathrm{g} \mathrm{cm}^{-3}\right)}\right] \times 100
$$

\subsubsection{Calculation of Nutrient Uptake}

The nutrient uptake was estimated by multiplying the plant part's dry weight (oven dry weight) by the nutrient content using the formula below [36]:

$$
\text { Nutrient uptake }=\frac{\text { Nutrient concentration }(\%) \times \text { Dry weight }(\mathrm{g})}{100}
$$




\subsubsection{Percent Relative Data}

For each element, the relative data of the value were presented as percentages relative to the control [37].

$$
\text { Relative data }(\%)=\frac{\text { Treatment value }- \text { control value }}{\text { control value }} \times 100
$$

\subsection{Statistical Analysis}

An analysis of variance (ANOVA) was used to determine the statistical difference among various treatments using the $\mathrm{R}$ statistical software, and to detect significant differences between the treatment means, Tukey's test (HSD) at a 5\% level of confidence $(p<0.05)$ was considered. Pearson's correlation analysis was used to estimate the relationships among different selected parameters.

\section{Result}

3.1. Effect of Organic Amendments and Irrigation Management on Yield and Yield-Contributing Characters of Rice

The impact of organic amendments (OAs) on the plant height was significant at the level of 0.05 , but irrigation regimes and their interaction with OA did not have an impact (Table 1). For the same irrigation regime, a significantly taller plant was observed with EFBB treatment $(102.06 \mathrm{~cm}$ and $100.45 \mathrm{~cm}$ for AWD and CF respectively). There were no significant effects of irrigation regimes and their interaction with organic amendments on panicle length; however, under the AWD irrigation regime, an increased panicle length was observed from EFBB, RHB and compost treatments $(28.31 \mathrm{~cm}, 28.03 \mathrm{~cm}$ and 27.28 , respectively), but there was no significant difference under $\mathrm{CF}$ irrigation. For the number of tillers hill ${ }^{-1}$ under the AWD regime, OAs exhibited similar values and minima from the control and within CF regime, with the maximum observed from the RHB treatment and the minimum from the control. Moreover, the highest numbers of grains were produced from RHB (184.74) and EFBB (185.89) treatments under AWD and CF regimes, respectively, and the minimum from the control.

Table 1. Effect of organic amendments and irrigation management on yield and yield-contributing characters of rice.

\begin{tabular}{|c|c|c|c|c|c|c|c|c|}
\hline Irrigation & $\begin{array}{l}\text { Organic } \\
\text { Amend- } \\
\text { ments }\end{array}$ & $\begin{array}{l}\text { Plant } \\
\text { Height } \\
\text { (cm) }\end{array}$ & $\begin{array}{l}\text { Panicle } \\
\text { Length } \\
(\mathrm{cm})\end{array}$ & $\begin{array}{c}\text { Number of } \\
\text { Tillers } \\
\text { Hill }^{-1}\end{array}$ & $\begin{array}{c}\text { Number of } \\
\text { Grains } \\
\text { Panicle }^{-1}\end{array}$ & $\begin{array}{c}\text { Grain } \\
\text { Yield } \\
\left(\mathrm{g} \mathrm{pot}^{-1}\right)\end{array}$ & $\begin{array}{c}\text { Straw } \\
\text { Yield } \\
\left(\mathrm{g} \mathrm{pot}^{-1}\right)\end{array}$ & $\begin{array}{c}\text { Biological } \\
\text { Yield } \\
\left(\mathrm{g} \mathrm{pot}^{-1}\right)\end{array}$ \\
\hline \multirow{4}{*}{ AWD } & RHB & $100.06 \mathrm{bA}$ & $28.03 \mathrm{abA}$ & $27.23 \mathrm{aA}$ & $184.74 \mathrm{aA}$ & $241.12 \mathrm{aA}$ & $336.37 \mathrm{aA}$ & $577.49 \mathrm{aA}$ \\
\hline & EFBB & $102.06 \mathrm{aA}$ & $28.31 \mathrm{aA}$ & $26.54 \mathrm{aA}$ & $182.85 \mathrm{bB}$ & $235.15 \mathrm{bA}$ & $333.01 \mathrm{aA}$ & $568.16 \mathrm{aA}$ \\
\hline & Compost & $100.18 \mathrm{bA}$ & $27.28 \mathrm{abA}$ & $25.03 \mathrm{aA}$ & $182.17 \mathrm{bA}$ & $228.24 \mathrm{cA}$ & $314.96 \mathrm{bA}$ & $543.19 \mathrm{bA}$ \\
\hline & Control & $100.06 \mathrm{bA}$ & $27.10 \mathrm{bA}$ & $21.56 \mathrm{bA}$ & $180.70 \mathrm{cA}$ & $210.15 \mathrm{dA}$ & $306.32 \mathrm{bA}$ & $516.47 \mathrm{cA}$ \\
\hline \multirow{4}{*}{ CF } & RHB & $100.44 \mathrm{bA}$ & $27.50 \mathrm{aA}$ & $28.29 \mathrm{aA}$ & $184.79 \mathrm{bA}$ & $239.55 \mathrm{aA}$ & $338.77 \mathrm{aA}$ & $578.32 \mathrm{aA}$ \\
\hline & EFBB & $102.45 \mathrm{aA}$ & $27.70 \mathrm{aA}$ & $25.80 \mathrm{abA}$ & $185.89 \mathrm{aA}$ & $234.70 \mathrm{aA}$ & $336.18 \mathrm{aA}$ & $570.88 \mathrm{aA}$ \\
\hline & Compost & $100.50 \mathrm{bA}$ & $27.13 \mathrm{aA}$ & $23.63 \mathrm{bcA}$ & $181.78 \mathrm{cA}$ & $233.57 \mathrm{aA}$ & $318.28 \mathrm{bA}$ & $551.85 \mathrm{bA}$ \\
\hline & Control & 99.86 bA & $27.50 \mathrm{aA}$ & $20.69 \mathrm{cB}$ & $178.76 \mathrm{~dB}$ & $211.13 \mathrm{bA}$ & $314.46 \mathrm{bA}$ & $525.59 \mathrm{cA}$ \\
\hline \multicolumn{9}{|c|}{ ANOVA } \\
\hline \multicolumn{2}{|c|}{ Irrigation } & ns & ns & ns & ns & ns & * & $* *$ \\
\hline \multicolumn{2}{|c|}{ Organic amendments } & $* * *$ & * & $* * *$ & * & $* * *$ & $* * *$ & $* * *$ \\
\hline \multicolumn{2}{|c|}{$\begin{array}{l}\text { Irrigation } \times \text { organic } \\
\text { amendments }\end{array}$} & ns & ns & ns & ns & ns & ns & ns \\
\hline
\end{tabular}

Notes: Different means with capital and small letters show a significant variation between irrigation practice and organic amendment. When two irrigation practices with the same organic amendment treatment exhibit the same capital letter, the means are not significantly different $(p<0.05)$. The means of various organic amendments are not statistically different under the same irrigation practice when followed by the same small letter $(p<0.05)$, based on the Tukey's test analysis; ns, not significant; and symbols *** and ***, denote significant changes among treatments at $p<0.05,0.01$ and 0.001, respectively. AWD: alternate wetting and drying; CF: continuous flooding; RHB: rice husk biochar; EFBB: oil palm empty fruit bunch biochar; control: no organic amendment. 
Grain, straw and biological yield were significantly enhanced due to the organic amendment treatment under the same irrigation regime (Table 1). For the AWD regime, RHB produced the maximum grain yield (241.12 $\left.\mathrm{g} \mathrm{pot}^{-1}\right)$ followed by EFBB $\left(235.15 \mathrm{~g} \mathrm{pot}^{-1}\right)$ and compost (228.24 $\left.\mathrm{g} \mathrm{pot}^{-1}\right)$, and the minimum was produced by thecontrol (210.15 $\mathrm{g} \mathrm{pot}^{-1}$ ). Under the CF regime, all the amendments produced similar but significantly higher yields compared to the control and CF irrigation regime. An increased straw yield under AWD (336.37 $\mathrm{g}$ and $333.01 \mathrm{~g} \mathrm{pot}^{-1}$ ) and increased biological yield (577.49 $\mathrm{g}$ and $568.18 \mathrm{~g} \mathrm{pot}^{-1}$ ) were caused by RHB and EFBB, respectively, while compost and control treatment exhibited reduced values. Similar trends of straw and biological yields were also observed for the $\mathrm{CF}$ irrigation regime. Considering the same $\mathrm{OA}$ treatment, there were no significant differences between AWD and CF irrigation regimes for grain, straw, and biological yields of rice.

\subsection{Effect of Irrigation Regimes and Organic Amendments on Leaf Chlorophyll Content at Major Growth Stages of Rice}

Leaf chlorophyll content (SPAD) was significantly affected $(p<0.05)$ by organic amendments with the same kind of irrigation during the tillering stage of rice (Figure 2). Considering the same regime, RHB, EFBB, and compost showed higher chlorophyll contents than the control, while for the same organic amendment (OA), there was no significant difference between AWD and CF irrigation regimes. During the flowering stage, a similar trend was observed from OA treatment under AWD, but for the CF regime, there were no significant differences among OA treatments. During the flowering for AWD, a similar trend was observed from OA treatment, but for the CF regime, there were no significant differences among OA treatments. For the same OA treatment, compost and control exhibited lower chlorophyll contents (up to 7\%) in the AWD regime over CF, but RHB and EFBB produced similar values. Meanwhile, during the grain filling stage, in the AWD regime, the highest chlorophyll content was observed from EFBB (46.53), which was similar to RHB and compost, and the minimum was obtained by the control (at 44.35, 43.60 and 41.25 respectively); in the CF regime, all the amendments showed a higher value than the control. As with the tillering stage, with thesame OA treatment, AWD and CF irrigation regimes exhibited statistically similar values of chlorophyll content during the grain filling stage of rice.

$\square$ RHB $\square$ EFBB $\square$ Compost $\square$ Control

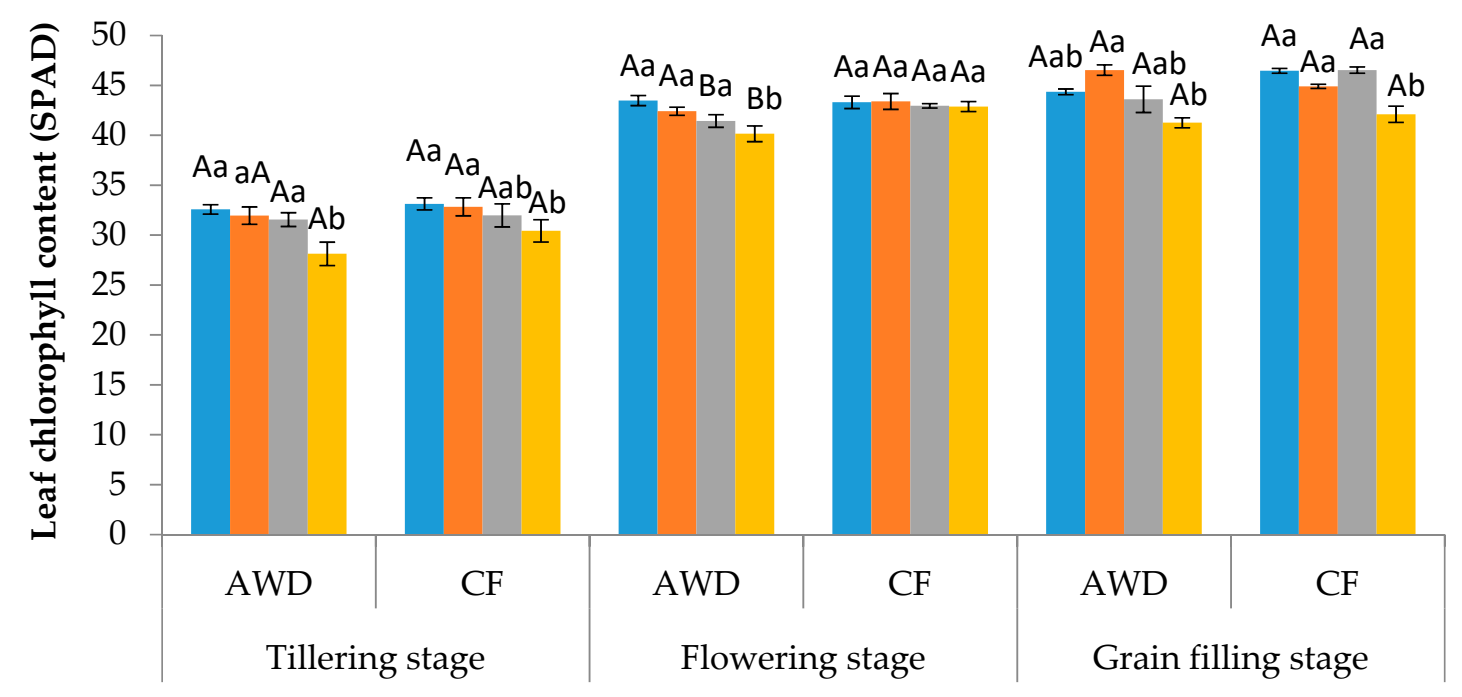

Irrigation and growth stages of rice

Figure 2. Effects of irrigation regimes and organic amendments on leaf chlorophyll content at major growth stages of rice. Notes: Different means with capital and small letters show a significant variation between irrigation practice and organic 
amendment. When two irrigation practices with the same organic amendment treatment exhibit the same capital letter, the means are not significantly different $(p<0.05)$. The means of various organic amendments are not statistically different under the same irrigation practice when followed by the same small letter $(p<0.05)$, based on the Tukey's test analysis. $\mathrm{AWD}$, alternate wetting and drying; $\mathrm{CF}$, continuous flooding; RHB, rice husk biochar, EFBB, oil palm empty fruit bunch biochar; control, no organic amendments.

\subsection{Effect of Organic Amendments and Irrigation Management on Irrigation Water Volume,} Water Use Efficiency and Carbon Isotope Discrimination of Rice

The effect of the irrigation regime and organic amendment significantly impacted $(p<0.05)$ the total irrigation water volume, but their interaction was not significant (Table 2). With AWD irrigation, RHB and EFBB significantly reduced the irrigation water volume (92.00 and 98.13 L, respectively), and a higher and similar irrigation water volume was observed from compost and control (108.10 and 110.75 L, respectively); simultaneously, similar trends were also observed from CF with organic amendments. For the same OA treatment, CF irrigation used a significantly greater $(p<0.05)$ irrigation water volume. The water use efficiency (WUE) of rice is significantly influenced by irrigation regimes, OAs and their interactions. For the same OA treatments, the AWD regime significantly enhanced water use efficiency compared to the CF irrigation regime. With the AWD irrigation regime, the maximum WUE was exhibited by RHB $\left(6.30 \mathrm{~g} \mathrm{~L}^{-1}\right)$ followed by $\operatorname{EFBB}\left(5.80 \mathrm{~g} \mathrm{~L}^{-1}\right)$, and the minimum was observed from the control (4.67). Moreover, the CF regime's addition of RHB and EFBB slightly increased (4.90 and $\left.4.73 \mathrm{~g} \mathrm{~L}^{-1}\right)$ the WUE compared to compost $\left(4.42 \mathrm{~g} \mathrm{~L}^{-1}\right)$, and the lowest was exhibited by the control $\left(3.94 \mathrm{~g} \mathrm{~L}^{-1}\right)$. Carbon isotope discrimination (\% $\left.\Delta \mathrm{C}\right)$ in plant tissue was used to detect the level of drought stress faced by theplant. Considering the same OA treatment, except for the control, there were no significant differences between AWD and CF irrigation regimes for $\% \Delta \mathrm{C}$ in rice leaf. For the AWD irrigation regime, RHB, EFBB, and compost showed statistically similar values $(22.16,21.72$ and $21.57 \%$ respectively), while lower values were found from the control (18.53\%o); furthermore, for the CF irrigation regime, all the OAs including the control produced similar values.

Table 2. Effect of irrigation management and organic amendments on irrigation water volume, water use efficiency and leaf carbon isotope discrimination of rice.

\begin{tabular}{|c|c|c|c|c|}
\hline Irrigation & $\begin{array}{c}\text { Organic } \\
\text { Amendments }\end{array}$ & $\begin{array}{c}\text { Volume of Water } \\
\text { Used (L) }\end{array}$ & $\begin{array}{l}\text { Water Use Efficiency } \\
\qquad\left(\mathrm{g} \mathrm{L}^{-1}\right)\end{array}$ & $\% \Delta \mathrm{C}$ in Leaf \\
\hline \multirow{4}{*}{ AWD } & RHB & $92.00 \mathrm{bB}$ & $6.30 \mathrm{aA}$ & $22.16 \mathrm{aA}$ \\
\hline & EFBB & $98.13 \mathrm{bB}$ & $5.80 \mathrm{bA}$ & $21.72 \mathrm{aA}$ \\
\hline & Compost & $108.10 \mathrm{aB}$ & $5.03 \mathrm{cA}$ & $21.57 \mathrm{aA}$ \\
\hline & Control & $110.75 \mathrm{aB}$ & $4.67 \mathrm{cA}$ & $18.53 \mathrm{bB}$ \\
\hline \multirow{4}{*}{$\mathrm{CF}$} & RHB & $118.5 \mathrm{bA}$ & $4.90 \mathrm{aB}$ & $22.43 \mathrm{aA}$ \\
\hline & EFBB & $120.73 \mathrm{bA}$ & $4.73 \mathrm{abB}$ & $23.28 \mathrm{aA}$ \\
\hline & Compost & $125.15 \mathrm{abA}$ & $4.42 \mathrm{bB}$ & $22.53 \mathrm{aA}$ \\
\hline & Control & $133.5 \mathrm{aA}$ & $3.94 \mathrm{cB}$ & $22.20 \mathrm{aA}$ \\
\hline \multicolumn{5}{|c|}{ ANOVA } \\
\hline \multicolumn{2}{|c|}{ Irrigation } & $* * *$ & $* * *$ & $* * *$ \\
\hline \multicolumn{2}{|c|}{ Organic amendments } & $* * *$ & $* * *$ & $* *$ \\
\hline \multicolumn{2}{|c|}{ Irrigation $\times$ organic amendments } & ns & ** & * \\
\hline
\end{tabular}

Notes: Different means with capital and small letters show a significant variation between irrigation practice and organic amendment. When two irrigation practices with the same organic amendment treatment exhibit the same capital letter, the means are not significantly different $(p<0.05)$. The means of various organic amendments are not statistically different under the same irrigation practice, followed by the same small letter $(p<0.05)$ based on the Tukey's test analysis; ns, not significant; and symbols *,** and ${ }^{* * *}$ denote significant changes among treatments at $p<0.05,0.01$ and 0.001, respectively. AWD: alternate wetting and drying; CF: continuous flooding; RHB: rice husk biochar; EFBB: oil palm empty fruit bunch biochar; control: no organic amendment. 
3.4. Effect of Organic Amendments (RHB, EFBB, Compost and Control) on Percentage of Soil Moisture Content at Different Drying Cycles of Alternate Wetting and Drying Irrigation

The addition of different organic amendments significantly influenced the soil moisture content at different drying cycles of the AWD irrigation regime. From Figure 3 , it was observed that, in the first drying cycle, RHB, EFBB and the control showed similar soil moisture contents, which were significantly greater compared to compost. However, in the rest of the drying cycles, two biochars (RHB and EFBB) exhibited a somewhat higher moisture content compared to others, and the minimum was observed from the control treatment, which was similar to compost except in the 8th (D8) and 10th (D10) drying cycles. Overall, the application of different organic amendments with the AWD irrigation regime increased the soil moisture content in various drying cycles.

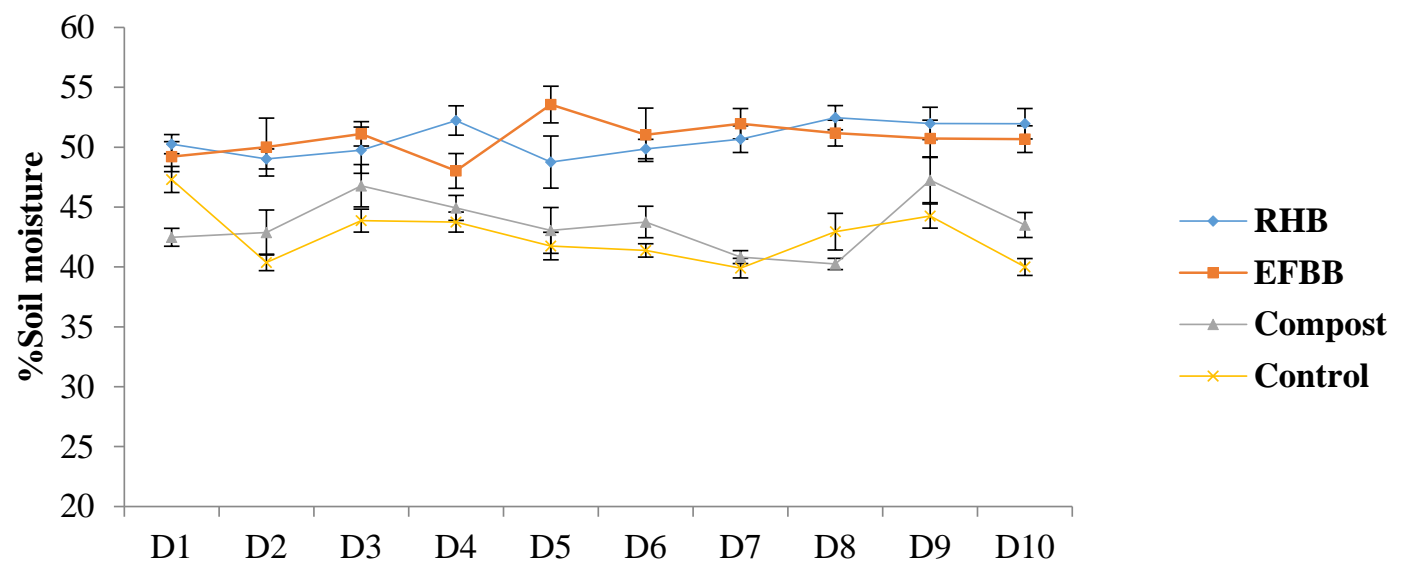

\section{Drying cycles in AWD irrigation}

Figure 3. Effect of organic amendments (RHB, EFBB, compost and control) on percentage of soil moisture content at different drying cycles of alternate wetting and drying irrigation. Vertical bars in the graph indicate the standard error of means ( \pm SE, $n=4)$. RHB, AWD: alternate wetting and drying; RHB: rice husk biochar; EFBB: oil palm empty fruit bunch biochar; control: no organic amendment.

\subsection{Effect of Organic Amendments and Irrigation Management on Nutrient Contents in Plant Parts}

Under the same irrigation regime, the maximum nitrogen $(\mathrm{N})$ concentration in grain was found in EFBB under AWD (16.68 $\left.\mathrm{g} \mathrm{kg}^{-1}\right)$ and CF $\left(16.70 \mathrm{~g} \mathrm{~kg}^{-1}\right)$ irrigation regimes and the minimum from the control $\left(10.25 \mathrm{~g} \mathrm{~kg}^{-1}\right)$. Furthermore, the maximum $\mathrm{N}$ in straw was obtained by RHB $\left(8.18 \mathrm{~g} \mathrm{~kg}^{-1}\right)$ under the AWD regime, which was similar to EFBB $\left(7.13 \mathrm{~g} \mathrm{~kg}^{-1}\right)$ and compost $\left(6.10 \mathrm{~g} \mathrm{~kg}^{-1}\right)$ (Table 3), but significantly higher than the control $\left(13.53 \mathrm{~g} \mathrm{~kg}^{-1}\right)$. With the $\mathrm{CF}$ regime, all the OA treatments showed similar results. For the same OA, compost and control with the $\mathrm{CF}$ regime exhibited significantly higher grain $\mathrm{N}$ over AWD irrigation, but for straw $\mathrm{N}$, there was no significant variation. Regarding phosphorus concentration in grain under AWD irrigation, all the OAs showed similar values, but a significantly higher value than the control; however, under $\mathrm{CF}$, all the OA treatments produced similar values. The application of OA improved the $\mathrm{P}$ concentration in straw under both irrigation regimes. For the same OA treatment, a significantly higher $\mathrm{P}$ content in grain was obtained by the control with $\mathrm{CF}$ compared to AWD (4.54 and $3.37 \mathrm{~g} \mathrm{~kg}^{-1}$ respectively). Moreover, greater straw $\mathrm{P}$ was obtained by CF with compost and the control over AWD irrigation. The addition of biochar (RHB and EFBB) with two irrigation regimes increased the $K$ concentration in rice grain compared to compost and the control, but the highest straw $\mathrm{K}$ concentration was found in the EFBB treatment, as other OA treatments produced closer results. Considering the same OA, compost and the control with $\mathrm{CF}$ exhibited significantly greater $\mathrm{K}$ contents in grain (2.50 
and $2.11 \mathrm{~g} \mathrm{~kg}^{-1}$, respectively) and straw (13.74 and $13.71 \mathrm{~g} \mathrm{~kg}^{-1}$, respectively) compared to the AWD irrigation regime, while no variation was found in RHB and EFBB for the $\mathrm{CF}$ irrigation regime. The incorporation of $\mathrm{OA}$ in two irrigation regimes enhanced the calcium content in grain and straw over the control, but in thecaseof the same OA, there was no significant effect due to AWD and CF irrigation on the Caconcentration in grain and straw of rice. Likewise, the magnesium $(\mathrm{Mg})$ concentration in rice grain and straw significantly increased due to biochar and compost compared to the control. Under the same $\mathrm{OA}$ treatment, the $\mathrm{Mg}$ concentration of grain and straw sharply increased in the $\mathrm{CF}$ compared to the AWD irrigation regime.

Table 3. Effect of organic amendments and irrigation management on nutrient contents in plants.

\begin{tabular}{|c|c|c|c|c|c|c|c|c|c|c|c|}
\hline \multirow{2}{*}{ Irrigation } & \multirow{2}{*}{$\begin{array}{c}\text { Organic } \\
\text { Amendments }\end{array}$} & \multicolumn{2}{|c|}{$N\left(g^{k g}{ }^{-1}\right)$} & \multicolumn{2}{|c|}{$P\left(g^{k g}{ }^{-1}\right)$} & \multicolumn{2}{|c|}{$\mathrm{K}\left(\mathrm{g} \mathrm{kg}^{-1}\right)$} & \multicolumn{2}{|c|}{$\mathrm{Ca}\left(\mathrm{g} \mathrm{kg}^{-1}\right)$} & \multicolumn{2}{|c|}{$\operatorname{Mg}\left(g^{k g}{ }^{-1}\right)$} \\
\hline & & Grain & Straw & Grain & Straw & Grain & Straw & Grain & Straw & Grain & Straw \\
\hline \multirow{4}{*}{ AWD } & RHB & $\begin{array}{c}14.48 \\
\mathrm{bA}\end{array}$ & $8.18 \mathrm{aA}$ & $\begin{array}{l}4.97 \\
\mathrm{aA}\end{array}$ & $\begin{array}{l}1.94 \\
\mathrm{aA}\end{array}$ & $2.60 \mathrm{aA}$ & $\begin{array}{l}13.60 \\
\mathrm{abA}\end{array}$ & $0.48 \mathrm{abA}$ & $\begin{array}{l}4.14 \\
\mathrm{aA}\end{array}$ & $\begin{array}{c}0.68 \\
\mathrm{aB}\end{array}$ & $\begin{array}{l}1.88 \\
\mathrm{aA}\end{array}$ \\
\hline & EFBB & $\begin{array}{c}16.78 \\
\mathrm{aA}\end{array}$ & $7.13 \mathrm{abA}$ & $\begin{array}{l}4.50 \\
\mathrm{aA}\end{array}$ & $\begin{array}{l}1.77 \\
\mathrm{abA}\end{array}$ & $2.81 \mathrm{aA}$ & $\begin{array}{c}14.22 \\
\mathrm{aA}\end{array}$ & $0.50 \mathrm{abA}$ & $\begin{array}{l}4.13 \\
\mathrm{aA}\end{array}$ & $\begin{array}{c}0.72 \\
\mathrm{aA}\end{array}$ & $\begin{array}{l}1.82 \\
\mathrm{aA}\end{array}$ \\
\hline & Compost & $\begin{array}{c}15.15 \\
\mathrm{abB}\end{array}$ & $6.10 \mathrm{abA}$ & $\begin{array}{l}4.28 \\
\mathrm{aA}\end{array}$ & $\begin{array}{l}1.66 \\
\mathrm{bB}\end{array}$ & $1.76 \mathrm{bB}$ & $\begin{array}{c}12.51 \\
\mathrm{abB}\end{array}$ & $0.65 \mathrm{aA}$ & $\begin{array}{l}4.68 \\
\mathrm{aA}\end{array}$ & $\begin{array}{l}0.70 \\
\mathrm{aA}\end{array}$ & $\begin{array}{c}1.61 \\
\mathrm{aB}\end{array}$ \\
\hline & Control & $\begin{array}{c}10.25 \\
\mathrm{cB}\end{array}$ & $5.00 \mathrm{bA}$ & $\begin{array}{c}3.37 \\
\mathrm{bB}\end{array}$ & $\begin{array}{c}1.40 \\
\mathrm{cB}\end{array}$ & $1.55 \mathrm{bB}$ & $\begin{array}{c}10.29 \\
b B\end{array}$ & $0.38 \mathrm{bA}$ & $\begin{array}{c}3.48 \\
\mathrm{bA}\end{array}$ & $\begin{array}{l}0.54 \\
\mathrm{bA}\end{array}$ & $\begin{array}{l}1.60 \\
\mathrm{aA}\end{array}$ \\
\hline \multirow{4}{*}{$\mathrm{CF}$} & RHB & $\begin{array}{l}15.00 \\
\mathrm{abA}\end{array}$ & $7.45 \mathrm{aA}$ & $\begin{array}{c}5.22 \\
\mathrm{aA}\end{array}$ & $\begin{array}{l}1.96 \\
\mathrm{aA}\end{array}$ & $2.74 \mathrm{abA}$ & $\begin{array}{c}14.06 \\
\mathrm{bA}\end{array}$ & $0.66 \mathrm{abA}$ & $\begin{array}{l}4.32 \\
\mathrm{abA}\end{array}$ & $\begin{array}{l}0.74 \\
\mathrm{aA}\end{array}$ & $\begin{array}{l}1.84 \\
\mathrm{aA}\end{array}$ \\
\hline & EFBB & $\begin{array}{c}16.70 \\
\mathrm{aA}\end{array}$ & $6.80 \mathrm{aA}$ & $\begin{array}{l}4.82 \\
\mathrm{aA}\end{array}$ & $\begin{array}{l}1.83 \\
\mathrm{abA}\end{array}$ & $2.92 \mathrm{aA}$ & $\begin{array}{c}16.84 \\
\mathrm{aA}\end{array}$ & $0.77 \mathrm{aA}$ & $\begin{array}{l}4.22 \\
\mathrm{abA}\end{array}$ & $\begin{array}{l}0.70 \\
\mathrm{abA}\end{array}$ & $\begin{array}{l}1.72 \\
\mathrm{abA}\end{array}$ \\
\hline & Compost & $\begin{array}{l}15.50 \\
\mathrm{abA}\end{array}$ & $6.35 \mathrm{aA}$ & $\begin{array}{l}4.63 \\
\mathrm{aA}\end{array}$ & $\begin{array}{l}1.84 \\
a b A\end{array}$ & $2.50 \mathrm{bcA}$ & $\begin{array}{c}13.74 \\
\mathrm{bA}\end{array}$ & $0.79 \mathrm{aA}$ & $\begin{array}{l}4.79 \\
\mathrm{aA}\end{array}$ & $\begin{array}{l}0.68 \\
\mathrm{bA}\end{array}$ & $\begin{array}{l}1.65 \\
\mathrm{bA}\end{array}$ \\
\hline & Control & $\begin{array}{c}13.53 \\
\mathrm{bA}\end{array}$ & $5.75 \mathrm{aA}$ & $\begin{array}{l}4.54 \\
\mathrm{aA}\end{array}$ & $\begin{array}{l}1.75 \\
\mathrm{bA}\end{array}$ & $2.11 \mathrm{cA}$ & $\begin{array}{c}13.31 \\
\mathrm{bA}\end{array}$ & $0.53 \mathrm{bA}$ & $\begin{array}{l}3.91 \\
\mathrm{bA}\end{array}$ & $\begin{array}{c}0.61 \\
\mathrm{cA}\end{array}$ & $\begin{array}{l}1.61 \\
\mathrm{bA}\end{array}$ \\
\hline & & & & ANOV & & & & & & \\
\hline \multicolumn{2}{|c|}{ Irrigation } & $* *$ & ns & $* *$ & $* * *$ & $* * *$ & $* * *$ & $* * *$ & * & ns & ns \\
\hline \multicolumn{2}{|c|}{ Organic amendments } & $* * *$ & * & $* * *$ & $* * *$ & $* * *$ & $* * *$ & $* *$ & $* * *$ & $* * *$ & * \\
\hline \multicolumn{2}{|c|}{$\begin{array}{l}\text { Irrigation } \times \text { organic } \\
\text { amendments }\end{array}$} & $* *$ & ns & ns & $* *$ & $* *$ & ns & ns & ns & ns & ns \\
\hline
\end{tabular}

Notes: Different means with capital and small letters show a significant variation between irrigation practice and organic amendments. When two irrigation practices with the same organic amendment treatment exhibit the same capital letter, the means are not significantly different $(p<0.05)$. The means of various organic amendments are not statistically different under the same irrigation practice when followed by the same small letter $(p<0.05)$, based on the Tukey's test analysis; ns, not significant; and symbols * ${ }^{* *}$ and ${ }^{* *}$ denote significant changes among treatments at $p<0.05,0.01$ and 0.001, respectively. AWD: alternate wetting and drying; CF: continuous flooding; RHB: rice husk biochar; EFBB: oil palm empty fruit bunch biochar; control: no organic amendment.

\subsection{Effect of Organic Amendments and Irrigation Management on Nutrient Uptake by Rice}

There was a significant $(p<0.05)$ effect of OA on the $\mathrm{N}$ uptake by rice plants, though irrigation and its interaction did not have an impact (Table 4). Under the AWD irrigation regime, RHB, EFBB and compost showed similar $\mathrm{N}$ uptake values $(6.24,6.31$ and $5.46 \mathrm{~g} \mathrm{pot}^{-1}$, respectively), but these were significantly higher than the control $\left(3.69 \mathrm{~g} \mathrm{pot}^{-1}\right)$. Similar trends were also observed for CF irrigation. The addition of RHB and EFBB improved the $P$ uptake within the AWD regime (1.85 and $1.65 \mathrm{~g} \mathrm{pot}^{-1}$, respectively) and CF (1.91 and $1.75 \mathrm{~g} \mathrm{pot}^{-1}$, respectively) compared to compost (1.50 and $1.67 \mathrm{~g} \mathrm{pot}^{-1}$, respectively) and the control (1.14 and $1.51 \mathrm{~g} \mathrm{pot}^{-1}$, respectively). Under the AWD irrigation, all the amendments increased $\mathrm{K}$ uptake over the control as the maximum was found for EFBB (6.35 $\mathrm{g} \mathrm{pot}^{-1}$ ) followed by RHB, compost and the control $(5.42,4.96$ and 4.63, respectively). For both irrigation regimes, all amendments exhibited a similar but significantly higher $\mathrm{Ca}$ uptake over the control. In the case of $\mathrm{Mg}$, under AWD irrigation, enhanced Mg uptake was obtained by RHB and EFBB ( 0.80 and $\left.0.77 \mathrm{~g} \mathrm{pot}^{-1}\right)$ over compost and the control (0.67 and $\left.0.60 \mathrm{~g} \mathrm{pot}^{-1}\right)$; furthermore, under $\mathrm{CF}$ irrigation greater $\mathrm{Mg}$ uptake was observed from RHB $\left(0.80 \mathrm{~g} \mathrm{pot}^{-1}\right)$ followed by EFBB $\left(0.74 \mathrm{~g} \mathrm{pot}^{-1}\right)$ compared to compost 
and the control (0.68 and 0.63 , respectively). Considering the same OA treatment, there was no significant variation $(p<0.05)$ between AWD and CF irrigation regimes for $\mathrm{N}$, $\mathrm{Ca}$ and $\mathrm{Mg}$ uptake. For the control, $\mathrm{P}$ and $\mathrm{K}$ uptake exhibited significantly different values between the irrigation regimes, while no statistical difference was observed for RHB, EFBB and compost.

Table 4. Effect of organic amendments and irrigation management on nutrient uptake by rice.

\begin{tabular}{|c|c|c|c|c|c|c|}
\hline Irrigation & $\begin{array}{c}\text { Organic } \\
\text { Amendments }\end{array}$ & $\begin{array}{l}\text { Nitrogen } \\
\left(g_{\text {pot }}-1\right)\end{array}$ & $\begin{array}{l}\text { Phosphorus } \\
\quad\left(\mathrm{g} \mathrm{pot}^{-1}\right)\end{array}$ & $\begin{array}{l}\text { Potassium } \\
\left(\mathrm{g} \mathrm{pot}^{-1}\right)\end{array}$ & $\begin{array}{l}\text { Calcium } \\
\left(\mathrm{g} \mathrm{pot}^{-1}\right)\end{array}$ & $\begin{array}{l}\text { Magnesium } \\
\left(\mathrm{g} \mathrm{pot}^{-1}\right)\end{array}$ \\
\hline \multirow{4}{*}{ AWD } & RHB & $6.24 \mathrm{aA}$ & $1.85 \mathrm{aA}$ & $5.20 \mathrm{aA}$ & $1.51 \mathrm{aA}$ & $0.80 \mathrm{aA}$ \\
\hline & EFBB & $6.31 \mathrm{aA}$ & $1.65 \mathrm{abA}$ & $5.39 \mathrm{aA}$ & $1.49 \mathrm{aA}$ & $0.77 \mathrm{aA}$ \\
\hline & Compost & $5.46 \mathrm{aA}$ & $1.50 \mathrm{bA}$ & $4.35 \mathrm{abA}$ & $1.62 \mathrm{aA}$ & $0.67 \mathrm{bA}$ \\
\hline & Control & $3.69 \mathrm{bA}$ & $1.14 \mathrm{cB}$ & $3.48 \mathrm{bB}$ & $1.15 \mathrm{bA}$ & $0.60 \mathrm{bA}$ \\
\hline \multirow{4}{*}{$\mathrm{CF}$} & RHB & $6.12 \mathrm{aA}$ & $1.91 \mathrm{aA}$ & $5.42 \mathrm{bA}$ & $1.62 \mathrm{aA}$ & $0.80 \mathrm{aA}$ \\
\hline & EFBB & $6.19 \mathrm{aA}$ & $1.75 \mathrm{abA}$ & $6.35 \mathrm{aA}$ & $1.60 \mathrm{aA}$ & $0.74 \mathrm{bA}$ \\
\hline & Compost & $5.56 \mathrm{abA}$ & $1.67 \mathrm{bcA}$ & $4.96 \mathrm{bcA}$ & $1.71 \mathrm{aA}$ & $0.68 \mathrm{cA}$ \\
\hline & Control & $4.67 \mathrm{bA}$ & $1.51 \mathrm{cA}$ & $4.63 \mathrm{cA}$ & $1.34 \mathrm{bA}$ & $0.63 \mathrm{cA}$ \\
\hline \multicolumn{7}{|c|}{ ANOVA } \\
\hline \multicolumn{2}{|c|}{ Irrigation } & ns & $* * *$ & $* * *$ & $* * *$ & ns \\
\hline \multicolumn{2}{|c|}{ Organic amendments } & $* * *$ & $* * *$ & $* * *$ & $* * *$ & $* * *$ \\
\hline \multicolumn{2}{|c|}{ Irrigation $\times$ Organic amendments } & ns & * & ns & ns & ns \\
\hline
\end{tabular}

Notes: Different means with capital and small letters show a significant variation between irrigation practice and organic amendments. When two irrigation practices with the same organic amendment treatment exhibit the same capital letter, the means are not significantly different $(p<0.05)$. The means of various organic amendments are not statistically different under the same irrigation practice when followed by the same small letter $(p<0.05)$, based on Tukey's test analysis; ns, not significant; and symbols * and *** denote significant changes among treatments at $p<0.05$ and 0.001 , respectively. AWD: alternate wetting and drying; CF: continuous flooding; RHB: rice husk biochar; EFBB: oil palm empty fruit bunch biochar; control: no organic amendment.

\subsection{Effect of Organic Amendments and Irrigation Management on Chemical Properties of Paddy Soil}

The post-harvest soil $\mathrm{pH}$ significantly varied $(p<0.05)$ according to irrigation regimes, $\mathrm{OA}$ and their combination, while the cation exchange capacity (CEC) was only influenced by OA (Table 5). Under the AWD regime, RHB and EFBB exhibited slightly higher $\mathrm{pH}$ values (6.20 and 6.37, respectively) followed by compost (6.04) and the lowest was obtained by the control (5.27); for the CF regime, the maximum $\mathrm{pH}$ value was observed from EFBB (6.55) followed by RHB (6.32) and compost (6.31), and the minimum was from the control (5.84). Within AWD and CF regimes, greater CEC was shown by RHB (19.45 and $19.81 \mathrm{cmol}_{\mathrm{C}} \cdot \mathrm{kg}^{-1}$, respectively) and EFBB (19.13 and $18.91 \mathrm{cmol}_{\mathrm{C}} \cdot \mathrm{kg}^{-1}$, respectively) and the lowest from the control (16.27 and $16.10 \mathrm{cmol}_{\mathrm{C}} \cdot \mathrm{kg}^{-1}$, respectively). Moreover, the CEC value of soil was not significantly affected between AWD and CF irrigation regimes for the same OA. As with CEC, higher values of soil total carbon (STC) under AWD and CF were observed from RHB (6.81\% and 6.90\%, respectively) and EFBB $(7.05 \%$ and $7.17 \%$, respectively) compared to compost (5.32 and 6.01, respectively) and the control (4.05\% and $5.80 \%$, respectively), but for the same OA treatment under AWD, only the control produced a lower value of STC in the CF regime, while others gave similar values for both irrigation regimes. 
Table 5. Effects of organic amendments and irrigation management on chemical properties of the paddy soil at harvest.

\begin{tabular}{|c|c|c|c|c|c|c|c|c|c|}
\hline Irrigation & $\begin{array}{c}\text { Organic } \\
\text { Amendments }\end{array}$ & $\mathrm{pH}$ & $\begin{array}{c}\mathrm{CEC} \\
\left(\mathrm{cmol}_{\mathrm{c}} \cdot \mathrm{kg}^{-1}\right)\end{array}$ & $\begin{array}{c}\text { Total C } \\
(\%)\end{array}$ & Total N (\%) & $\begin{array}{c}\text { Available P } \\
\left(\mathrm{mg} \mathrm{kg}^{-1}\right)\end{array}$ & $\begin{array}{c}\text { Exchang. K } \\
\left(\mathrm{cmol}_{\mathrm{c}} \cdot \mathrm{kg}^{-1}\right)\end{array}$ & $\begin{array}{l}\text { Exchang. Ca } \\
\left(\mathrm{cmol}_{\mathrm{c}} \cdot \mathrm{kg}^{-1}\right)\end{array}$ & $\begin{array}{l}\text { Exchang. Mg } \\
\left(\mathrm{cmol}_{\mathrm{c}} \cdot \mathrm{kg}^{-1}\right)\end{array}$ \\
\hline \multirow{4}{*}{ AWD } & RHB & $6.20 \mathrm{abB}$ & $19.45 \mathrm{aA}$ & $6.81 \mathrm{aA}$ & $0.35 \mathrm{bA}$ & $13.75 \mathrm{aA}$ & $3.59 \mathrm{bB}$ & $11.79 \mathrm{bB}$ & $7.81 \mathrm{aA}$ \\
\hline & EFBB & $6.37 \mathrm{aA}$ & $19.13 \mathrm{aA}$ & $7.05 \mathrm{aA}$ & $0.38 \mathrm{aA}$ & $12.61 \mathrm{aA}$ & $5.09 \mathrm{aA}$ & $12.71 \mathrm{bB}$ & $8.95 \mathrm{aA}$ \\
\hline & Compost & $6.04 \mathrm{bB}$ & $17.88 \mathrm{abA}$ & $5.32 \mathrm{bA}$ & $0.41 \mathrm{aB}$ & $12.16 \mathrm{aB}$ & $3.69 \mathrm{bB}$ & $16.39 \mathrm{aB}$ & $7.51 \mathrm{aA}$ \\
\hline & Control & $5.27 \mathrm{cB}$ & $16.27 \mathrm{bA}$ & $4.05 \mathrm{cB}$ & $0.22 \mathrm{cB}$ & $8.07 \mathrm{bB}$ & $1.34 \mathrm{cB}$ & $5.06 \mathrm{cB}$ & $5.61 \mathrm{bA}$ \\
\hline \multirow{4}{*}{$\mathrm{CF}$} & RHB & $6.32 \mathrm{bA}$ & $19.81 \mathrm{aA}$ & $6.90 \mathrm{aA}$ & $0.37 \mathrm{bA}$ & $13.04 \mathrm{aA}$ & $3.98 \mathrm{bA}$ & $12.94 \mathrm{bA}$ & $7.31 \mathrm{abA}$ \\
\hline & EFBB & $6.55 \mathrm{aA}$ & $18.91 \mathrm{abA}$ & $7.17 \mathrm{aA}$ & $0.38 \mathrm{bA}$ & $12.67 \mathrm{aA}$ & $5.21 \mathrm{aA}$ & $13.72 \mathrm{bA}$ & $9.02 \mathrm{aA}$ \\
\hline & Compost & $6.31 \mathrm{bA}$ & $17.47 \mathrm{abA}$ & $6.01 \mathrm{bA}$ & $0.44 \mathrm{aA}$ & $14.13 \mathrm{aA}$ & $3.94 \mathrm{bA}$ & $17.95 \mathrm{aA}$ & $8.15 \mathrm{aA}$ \\
\hline & Control & $5.84 \mathrm{cA}$ & $16.10 \mathrm{bA}$ & $5.80 \mathrm{bA}$ & $0.27 \mathrm{cA}$ & $9.90 \mathrm{bA}$ & $2.15 \mathrm{cA}$ & $6.45 \mathrm{cA}$ & $5.67 \mathrm{bA}$ \\
\hline \multicolumn{10}{|c|}{ ANOVA } \\
\hline \multicolumn{2}{|c|}{ Irrigation } & $* * *$ & ns & $* * *$ & $* * *$ & * & $* * *$ & $* * *$ & ns \\
\hline \multicolumn{2}{|c|}{ Organic amendments } & $* * *$ & $* * *$ & $* * *$ & $* * *$ & $* * *$ & $* * *$ & $* * *$ & $* * *$ \\
\hline \multicolumn{2}{|c|}{$\begin{array}{l}\text { Irrigation } \times \text { organic } \\
\text { amendments }\end{array}$} & $* *$ & ns & $* *$ & * & $* *$ & $* *$ & ns & ns \\
\hline
\end{tabular}

Notes: Different means with capital and small letters show a significant variation between irrigation practice and organic amendment. When two irrigation practices with the same organic amendment treatment exhibit the same capital letter, the means are not significantly different $(p<0.05)$. The means of various organic amendments are not statistically different under the same irrigation practice when followed by the same small letter $(p<0.05)$, based on Tukey's test analysis; ns, not significant; and symbols *, **,***, denote significant changes among treatments at $p<0.05,0.01$, and 0.001 , respectively. AWD: alternate wetting and drying; CF: continuous flooding; RHB: rice husk biochar; EFBB: oil palm empty fruit bunch biochar; control: no organic amendment.

Under the AWD irrigation regime, compost and EFBB exhibited greater $(0.41 \%$ and $0.38 \%$ ) total soil nitrogen (STN) compared to RHB $(0.35 \%)$ and the control $(0.22 \%)$; a similar trend was also observed for the CF regime (Table 5). In the case of the same OA, RHB and EFBB exhibited similar values of STN under AWD and CF regimes, although significantly different $(p<0.05)$ values were obtained by compost and the control. The incorporation of RHB, EFBB and compost enhanced the available phosphorus (P) status of soil under AWD $\left(13.75,12.61\right.$ and $12.16 \mathrm{mg} \mathrm{kg}^{-1}$, respectively) and CF (13.04, 12.67 and $14.13 \mathrm{mg} \mathrm{kg}^{-1}$, respectively) over the control ( 8.07 and $9.90 \mathrm{mg} \mathrm{kg}^{-1}$, respectively). As with STN, for the same OA, significantly different $(p<0.05)$ values of available $\mathrm{P}$ were observed from compost and the control while RHB and EFBB showed similar values for AWD and CF regimes. Considering AWD irrigation, the maximum exchangeable potassium (K) was observed from EFBB $\left(5.09 \mathrm{cmol}_{\mathrm{c}} \cdot \mathrm{kg}^{-1}\right)$ followed by compost $\left(3.69 \mathrm{cmol}_{\mathrm{c}} \cdot \mathrm{kg}^{-1}\right)$ and RHB $\left(3.59 \mathrm{cmol}_{\mathrm{C}} \cdot \mathrm{kg}^{-1}\right)$, and the minimum was from the control $\left(1.34 \mathrm{cmol}_{\mathrm{c}} \cdot \mathrm{kg}^{-1}\right)$; furthermore, a similar trend was also exhibited by different $\mathrm{OAs}$ under the $\mathrm{CF}$ irrigation regime (Table 5). For the same OA except for EFBB, other amendments with CF significantly increased $(p<0.05)$ the exchangeable $\mathrm{K}$ of soil over the AWD irrigation regime.

Considering similar amendments, RHB, EFBB, compost and the control with the CF regime produced significantly greater $(p<0.05)$ exchangeable Ca in soil $(12.94,13.72$, 17.95 and $6.45 \mathrm{cmol}_{\mathrm{C}} \cdot \mathrm{kg}^{-1}$, respectively) compared to the AWD irrigation regime (11.79, $12.71,16.39$ and $5.06 \mathrm{cmol}_{\mathrm{C}} \cdot \mathrm{kg}^{-1}$, respectively) (Table 5). For both AWD and CF irrigation regimes, the highest soil exchangeable Ca was obtained by compost and the lowest from the control. All the amendments showed statistically similar and significantly higher values of exchangeable magnesium concentration of soil over the control under both irrigation regimes, but for the same OA, there was no significant difference $(p<0.05)$ between AWD and $\mathrm{CF}$ irrigation regimes (Table 5).

\subsection{Effect of Organic Amendments and Irrigation Management on Physical Properties of the Paddy Soil}

There were no significant effects $(p<0.05)$ of irrigation regimes and organic amendments, and their interactions with the particle density of soil and all the treatments showed similar values (Table 6). However, bulk density and total porosity were significantly influenced by organic amendments but not affected by irrigation regimes and their interactions. In the case of AWD irrigation, RHB and EFBB significantly reduced the bulk density of soil ( 0.88 and $0.91 \mathrm{~g} \mathrm{cc}^{-1}$ for RHB and EFBB, respectively) followed by compost $\left(1.02 \mathrm{~g} \mathrm{cc}^{-1}\right)$, and the maximum was observed from the control $\left(1.11 \mathrm{~g} \mathrm{cc}^{-1}\right)$; under the $\mathrm{CF}$ irrigation 
regime, a lower bulk density was observed for RHB and EFBB $\left(0.94\right.$ and $0.93 \mathrm{~g} \mathrm{cc}^{-1}$, respectively) and the highest from the control $\left(1.12 \mathrm{~g} \mathrm{cc}^{-1}\right)$. The addition of organic amendments in both irrigation regimes increased total soil porosity (Table 6). Considering the AWD regime, an increased value of total porosity was observed from RHB and EFBB $(58.70 \%$ and $57.74 \%$, respectively) and a slightly reduced value from compost $(54.44 \%)$, while the lowest was observed from the control $(50.30 \%)$. Under the $\mathrm{CF}$ regime, quite similar values of total porosity were observed from RHB and EFBB ( $57.04 \%$ and $57.59 \%$, respectively), which were significantly higher than compost and the control $(53.19 \%$ and $49.45 \%$, respectively). In the case of the same OA treatment, the bulk density and total porosity of soil were not significantly influenced by AWD and CF irrigation regimes.

Table 6. Effect of organic amendments and irrigation management on physical properties of the paddy soil.

\begin{tabular}{|c|c|c|c|c|}
\hline Irrigation & $\begin{array}{c}\text { Organic } \\
\text { Amendment }\end{array}$ & $\begin{array}{l}\text { Particle Density } \\
\qquad\left(\mathrm{g} \mathrm{cc}^{-1}\right)\end{array}$ & $\begin{array}{l}\text { Bulk Density } \\
\qquad\left(\mathrm{g} \mathrm{cc}^{-1}\right)\end{array}$ & $\begin{array}{c}\text { Total Porosity } \\
(\%)\end{array}$ \\
\hline \multirow{4}{*}{ AWD } & RHB & $2.13 \mathrm{aA}$ & $0.88 \mathrm{cA}$ & $58.70 \mathrm{aA}$ \\
\hline & EFBB & $2.16 \mathrm{aA}$ & $0.91 \mathrm{cA}$ & $57.74 \mathrm{aA}$ \\
\hline & Compost & $2.23 \mathrm{aA}$ & $1.02 \mathrm{bA}$ & $54.44 \mathrm{abA}$ \\
\hline & Control & $2.22 \mathrm{aA}$ & $1.11 \mathrm{aA}$ & $50.30 \mathrm{bA}$ \\
\hline \multirow{4}{*}{$\mathrm{CF}$} & RHB & $2.18 \mathrm{aA}$ & $0.94 \mathrm{cA}$ & $57.04 \mathrm{aA}$ \\
\hline & EFBB & $2.18 \mathrm{aA}$ & $0.93 \mathrm{cA}$ & $57.59 \mathrm{aA}$ \\
\hline & Compost & $2.19 \mathrm{aA}$ & $1.03 \mathrm{bA}$ & $53.19 \mathrm{bA}$ \\
\hline & Control & $2.20 \mathrm{aA}$ & $1.12 \mathrm{aA}$ & $49.45 \mathrm{cA}$ \\
\hline \multicolumn{5}{|c|}{ ANOVA } \\
\hline \multicolumn{2}{|c|}{ Irrigation } & ns & ns & ns \\
\hline \multicolumn{2}{|c|}{ Organic amendment } & ns & $* * *$ & $* * *$ \\
\hline \multicolumn{2}{|c|}{$\begin{array}{l}\text { Irrigation } \times \text { Organic } \\
\text { amendment }\end{array}$} & ns & ns & ns \\
\hline
\end{tabular}

Notes: Different means with capital and small letters show a significant variation between irrigation practice and organic amendment. When two irrigation practices with the same organic amendment treatment exhibit the same capital letter, the means are not significantly different $(p<0.05)$. The means of various organic amendments are not statistically different under the same irrigation practice when followed by the same small letter $(p<0.05)$ based on Tukey's test analysis; ns, not significant; and symbol ${ }^{* * *}$, denote significant changes among treatments at $p<0.001$. AWD: alternate wetting and drying; CF: continuous flooding; RHB: rice husk biochar; EFBB: oil palm empty fruit bunch biochar; control: no organic amendment.

\subsection{Relationship between Grain Yield, Nutrient Uptake and Physicochemical Properties of Soil}

Pearson's correlation analysis was performed to determine the relationship between grain yield, nutrient uptake and the physicochemical properties of soil (Table 7). Grain yield was positively and significantly correlated with WUE, N, $\mathrm{P}$ and $\mathrm{K}$ uptake $(\mathrm{r}=0.78$ **, $0.83^{* *}, 0.82^{* *}$ and $0.72{ }^{* *}$, respectively); furthermore, soil properties, such as $\mathrm{pH}, \mathrm{CEC}$ total $\mathrm{C}, \mathrm{N}$, and total porosity also showed a positive relationship $\left(\mathrm{r}=0.76^{* *}, 0.71^{* *}, 0.91^{* *}, 0.63^{* *}\right.$ and $0.85^{* *}$, respectively), while bulk density exhibited a negative relationship $\left(\mathrm{r}=-0.89^{* *}\right)$. Moreover, all the nutrient uptake, WUE and chemical properties of soil were found to be significantly and positively related to soil porosity, while a negative correlation was observed for bulk density. 
Table 7. Correlation coefficients between grain yield, water use efficiency, nutrient uptake and physicochemical properties of soil.

\begin{tabular}{|c|c|c|c|c|c|c|c|c|c|c|c|c|c|c|c|c|}
\hline & GY & WUE & N Uptake & P Uptake & K Uptake & Ca Uptake & Mg Uptake & $\mathrm{pH}$ & CEC & STC & STN & Av. $\mathbf{P}$ & Exchng. K & Exchng. Ca & Exchng. Mg & Bulk Density \\
\hline GY & & & & & & & & & & & & & & & & \\
\hline WUE & $0.78^{* *}$ & & & & & & & & & & & & & & & \\
\hline $\mathrm{N}$ uptake & 0.83 ** & 0.62 ** & & & & & & & & & & & & & & \\
\hline P uptake & $0.82 * *$ & 0.50 ** & $0.74 * *$ & & & & & & & & & & & & & \\
\hline K uptake & 0.72 ** & $0.39 *$ & $0.75^{* *}$ & $0.69 * *$ & & & & & & & & & & & & \\
\hline Ca uptake & 0.61 ** & $0.25^{\text {ns }}$ & $0.59^{* *}$ & $0.62 * *$ & 0.48 ** & & & & & & & & & & & \\
\hline Mg uptake & 0.80 ** & $0.69^{* *}$ & $0.73 * *$ & $0.63^{* *}$ & $0.69^{* *}$ & $0.38 *$ & & & & & & & & & & \\
\hline $\mathrm{pH}$ & 0.76 ** & $0.37 *$ & 0.78 ** & $0.77 * *$ & $0.79 * *$ & $0.80^{* *}$ & 0.58 ** & & & & & & & & & \\
\hline CEC & $0.71^{* *}$ & $0.56^{* *}$ & 0.52 ** & 0.59 ** & $0.46^{* *}$ & $0.40 *$ & 0.59 ** & 0.54 ** & & & & & & & & \\
\hline STC & 0.91 ** & $0.76^{* *}$ & $0.80^{* *}$ & 0.73 ** & $0.79^{* *}$ & $0.44^{*}$ & 0.75 ** & 0.71 ** & $0.68^{* *}$ & & & & & & & \\
\hline STN & $0.63^{* *}$ & $0.32^{\mathrm{ns}}$ & $0.67^{* *}$ & 0.56 ** & $0.49 * *$ & $0.80^{* *}$ & $0.45 *$ & 0.82 ** & $0.46^{* *}$ & $0.48 * *$ & & & & & & \\
\hline Exchng. K & $0.8^{* *}$ & 0.55 ** & $0.84^{* *}$ & $0.64 * *$ & $0.78^{* *}$ & 0.68 ** & $0.62 * *$ & 0.89 ** & $0.55 * *$ & 0.85 ** & $0.79 * *$ & $0.78^{* *}$ & & & & \\
\hline Exchng. Ca & $0.61 * *$ & $0.41 *$ & $0.64^{* *}$ & 0.51 ** & $0.39 *$ & $0.64 * *$ & $0.32^{\mathrm{ns}}$ & 0.67 ** & 0.38 * & 0.54 ** & $0.82 * *$ & $0.81 * *$ & $0.77^{* *}$ & & & \\
\hline Exchng. Mg & $0.85 * *$ & $0.62 * *$ & $0.81 * *$ & $0.70^{* *}$ & 0.59 & 0.78 ** & $0.62 * *$ & 0.83 ** & $0.60 * *$ & $0.72 * *$ & 0.91 ** & $0.94^{* *}$ & $0.87 * *$ & $0.83 * *$ & & \\
\hline Bulk density & $-0.89 * *$ & $-0.82^{* *}$ & $-0.85^{* *}$ & $-0.68^{* *}$ & $-0.70^{* *}$ & $-0.45^{*}$ & $-0.76^{* *}$ & $-0.63^{* *}$ & $-0.52^{* *}$ & $-0.88^{* *}$ & $-0.50^{* *}$ & $-0.61^{* *}$ & $-0.78^{* *}$ & $-0.58 * *$ & $-0.77^{* *}$ & \\
\hline Total porosity & 0.85 ** & $0.77^{* *}$ & 0.81 ** & $0.65 * *$ & $0.70^{* *}$ & $0.42 *$ & $0.71^{* *}$ & 0.63 ** & $0.48^{* *}$ & $0.84 * *$ & 0.50 ** & $0.59 * *$ & $0.76^{* *}$ & $0.58^{* *}$ & $0.76^{* *}$ & $-0.97 * *$ \\
\hline
\end{tabular}

GY: grain yield; WUE: water use efficiency; STC: soil total carbon; STN: soil total nitrogen; Av. P: available phosphorus; ${ }^{\text {ns: }}$ not significant; ${ }^{*} p<0.05 ;{ }^{* *} p<0.01$. 


\section{Discussion}

\subsection{Rice Yield and Water Use Efficiency}

One of the most essential components of adopting a rice cultivation method is the effect of that cultivation on grain yield. Previous studies on the effect of AWD on yield compared to other rice cultivation practices have reported varying impacts, from a reduction in yield to increases in yield [9,38-40]. In this study, plants grown with two irrigation regimes-AWD and CF- did not show a remarkable increase in grain, straw and the biological yield of rice with the same organic amendments (Table 1), sincethe addition of RHB, EFBB and compost increased grain yield upto $14 \%$ to $15 \%$ under both irrigation regimes. The improved rice yield due to the addition of biochar and compost was produced because of a favorable environment in the rhizospheric zone, which helps with the increased nutrient uptake by improving the physicochemical properties [41-43].

The most important aspect of adopting AWD irrigation is the reduced consumption of irrigation water with enhanced water use efficiency [9]. The incorporation of RHB and EFBB with AWD saves irrigation water at arate of $31 \%$ and $26 \%$, respectively, compared to the unamended pot with CF irrigation. Consecutively, under AWD irrigation, $16 \%$ and $11 \%$ of water use was reduced by the addition of RHB and EFBB, respectively. This saving of water increased the WUE by $35 \%$ and $24 \%$, respectively, due to the inclusion of RHB and EFBB under AWD irrigation. Overall, the addition of biochar with AWD increased WUE upto $60 \%$ compared to CF with the control. This indicates that two biochars could increase soil water retention by reducing soil moisture loss under water-saving irrigation. A porous structure, as well as a high surface area, could be observed from the internal structure of RHB and EFBB [44]. The improved moisture retention by biochar increases soil moisture storage directly due to its large surface area and high quantity of pores which act as a capillary reserve of water [45]. From a previous study, Chen et al. [46] reported that the incorporation of rice husk and rice straw biochar increased the soil water content of sandy loam soil by $6.53 \%$ and $18.61 \%$ and of silty loam soil by $8.70 \%$ and $19.66 \%$, respectively. Dong et al. [47] observed that, depending on the application rate of rice straw biochar and bamboo biochar, the soil moisture content increased up to $15 \%$ and $9 \%$, respectively, in the clay loam soil for rice cultivation. In clay soil, an increase of available water capacity with an increment rate of biochar was reported by Kameyama et al. [48]; furthermore, the addition of biochar increased gravimetric water content in clay-textured paddy soil asreported by Haque et al. [44].

Carbon isotope composition analysis can be used as an indication of plant moisture stress because, during drought conditions, plants demonstrate greater ${ }^{13} \mathrm{C}$ in the tissue, resulting in reduced discrimination against the heavier isotopes (lower ${ }^{13} \mathrm{C}$ readings) due to a decrease in stomatal conductance [49,50]. Centritto et al. [51] reported that, under drought stress, the vegetative tissue of rice showed reduced $\Delta^{13} \mathrm{C}$ values. From the carbon isotope discrimination analysis of rice leaf, all the OAs with $\mathrm{CF}$ irrigation produced similar values of $\Delta^{13} \mathrm{C}$, while AWD with the control showed a much lower value compared to other amended treatments. The result suggests that the minor drought stress faced by the rice plant in the unamended soil of AWD irrigation could be minimized by the addition of biochar or compost.

This study was conducted in a controlled environment with no water sources for the crop other than irrigation, and also the drainage system was absent due to the sealing at the bottom of the pot. Furthermore, in the field, rainfall acts as a water source, and a significant amount of water is lost due to percolation. Therefore, the irrigation requirement is expected to fluctuate in the field compared to this study.

\subsection{Nutrient Uptake and Changes in Physicochemical Properties of Soil}

Nutrient uptake by rice in CF varies from that in AWD due to rice's physiological response to lower nutrient availability in the AWD system [8]. In this study, the addition of OAs - especially RHB and EFBB - under AWD irrigation boosted the N, P, K, Ca and $\mathrm{Mg}$ uptake by rice. The higher nutrient concentration with improved rice yield due to the 
application of OAs in the AWD irrigation is mainly responsible for the increased nutrient uptake. This greater responsiveness to the nutrient uptake could be due to the enhanced available nutrients by the biochar with improved nutrient retention [52,53]. Baker et al. [54] found that under AWD irrigation, the application of EFBB at 0 to 40 ton ha ${ }^{-1}$ in a paddy soil increased N, P, K, Ca and Mg uptake up to $148 \%, 225 \%, 600 \%, 340 \%$ and $298 \%$, respectively. A meta-analysis by Biederman et al. [55] observed that biochar boosted $\mathrm{P}$ and $\mathrm{K}$ content in plants over fertilizer because it increased their availability by reducing leaching loss and soil liming.

Paddy soil in this study showed variations in $\mathrm{pH}$ that resulted mainly from the addition of biochar and compost and the intermittent drying of soils. Adding OA increased $\mathrm{pH}$ upto 1.1 and 0.71 units under AWD and CF irrigation, respectively. This change was mainly caused by the water content of the soil, the amount of neutral salts and the type of cations in soil solution and in exchange complexes [56]. Biochar itself exhibits a high pH due to the existence of carbonates and organic anions derived from acidic functional groups [57]; thus, it is used as a soil amendment to optimize soil $\mathrm{pH}$ for crop production [58].

About $43 \%$ of soil carbon was reduced in the unamended soil of AWD irrigation compared to $\mathrm{CF}$, though the addition of EFBB and RHB increased soil carbon by $85 \%$ to $68 \%$. The intermittent drying and wetting of soil induces SOC loss, as shown by Borken et al. [59] and Butterly et al. [60]. AWD produces greater aerobic conditions in the soil than flooded irrigation, which may increase the decomposition of plant waste and organic debris in the soil, particularly during rice's vegetative growth stage [61]. This may result in higher $\mathrm{CO}_{2}$ emissions from the soil due to decaying organic matter and a fall in the soil organic matter status [62-64]. According to Wang and Liu [65], biochar has unique features that improve long-term carbon storage in soil. The combined incorporation of biochar in watersaving irrigation practices enhances the SOC and its related factors [66]. Compost showed a maximum increase of total soil nitrogen (STN) of $86 \%$ to $67 \%$ under these two irrigation regimes, which could be due to the nitrogen-enriched amendments. The biochar used in this study also increased STN up to 72\% inAWD irrigation. By-pass or preferential flow and nitrogen transformation processes increase the nitrogen loss that occurs at AWD, potentially decreasing the effectiveness of the water-saving approach [67]. Ammonia $\left(\mathrm{NH}_{3}\right)$ adsorption by biochar decreases $\mathrm{NH}_{3}$ and $\mathrm{NO}_{3}{ }^{-}$losses during composting and after manure applications and offers a mechanism for developing slow-release fertilizers [68]. The increase in soil nitrogen due to biochar was also reported in previous studies $[41,47,54]$. Different organic amendments increased the available phosphorus in the post-harvestsoil under the two irrigation regimes. RHB and EFBB showed similar available P in AWD rather than $\mathrm{CF}$, while this decreased significantly under compost and control treatments. A similar trend of a reduction of nutrients in AWD was also observed for exchangeable potassium for all OA treatments except EFBB due to its high $\mathrm{K}$ content, although all OA's significantly increased exchangeable K from $167 \%$ to $280 \%$ under AWD irrigation. All the amendments showed significantly lower exchangeable calcium under AWD compared to CF irrigation as all the amendments increased the cation over the control. During drying cycles of AWD irrigation, watermoved to subsoil, which was responsible for the bypass flow of nutrients from the upper soil surface and made them unavailable to the rice root zone [69]. In this study, the addition of organic amendments - especially RHB and EFBB-increased the nutrient content of post-harvestsoil under AWD irrigation.

Biochar inclusion improves soil fertility in two ways: firstly, by adding nutrients to the soil; secondly, by adsorbing nutrients from other sources [70]. The porous structure, vast surface area, increased charge density and presence of polar and non-polar sites on the surface of biochar increases its ability to absorb nutrients, enrich soil fertility and prevent nutrient leaching [71]. Major et al. [72] observed that, due to the addition of wood biochar, the leaching of $\mathrm{K}^{+}, \mathrm{Ca}^{2+}, \mathrm{Mg}^{2+}$ and $\mathrm{NO}_{3}{ }^{-}$decreased $31 \%, 14 \%, 22 \%$ and $2 \%$, respectively. According to Luo et al. [73], biochar formed from agricultural residue functions as a $\mathrm{P}$ source similar to commercial $\mathrm{P}$ and $\mathrm{K}$ fertilizers, and it also improves $\mathrm{Ca}$ 
and Mg supply. Wang et al. [74] found that the addition of rice husk and sawdust biochar boosted exchangeable cations, such as $\mathrm{Ca}, \mathrm{Mg}$, $\mathrm{K}$, and $\mathrm{Na}$ by $60 \%$ to $70 \%$.

The addition of biochar and compost in the current study reduced bulk density up to $20 \%$ and boosted the total soil porosity up to $17 \%$. Furthermore, RHB and EFBB reduced bulk density (to $13.72 \%$ and $10.78 \%$, respectively) compared to compost, and soil porosity was increased to $7.83 \%$ and $8.27 \%$, respectively.The increased soil porosity and decreased bulk density due to biochar inclusion may be due to the highly porous biochar material contributing extra pores or the formation of packing or pores to modify the pore system [75].Głab et al. [19] found that adding biochar to soil reduced bulk density by up to $35 \%$, with the largest impact occurring when the soil was treated with $4 \%$ biochar. Depending on the rate, rice husk biochar increased soil porosity up to 19\% [20]. Moreover, Sun and Liu [76] found that the inclusion of straw wood chip and wastewater biochar in a Vertisol clay increased porosity by $100 \%, 68 \%$, and $36 \%$, respectively.

\section{Conclusions}

The alternate wetting and drying (AWD) irrigation regime is preferred over the continuous flooding (CF) for sustainable rice production as it produces a similar yield with improved water use efficiency. The addition of $4 \%$ organic amendments (biochar and compost) enhances the nutrient uptake and improves the physical and chemical properties of soil. AWD irrigation with biochar (RHB or EFBB) could be a better option for paddy soil management in the context of feasible rice cultivation as it could increase soil $\mathrm{pH}, \mathrm{CEC}$, total carbon, nitrogen, available $\mathrm{P}$ and essential exchangeable cations in the rhizosphere, thereby increasing nutrient uptake compared to unamended soil. Moreover, RHB and EFBB reduce bulk density and increase the soil porosity, as well assharply boosting soil moisture content during the drying cycles of AWD irrigation. Overall, the addition of organic amendments with CF irrigation increases rice yield and improves the physicochemical properties of soil, but it is not preferable due to the requirement ofhuge amounts of water, which results in a poor WUE compared to AWD irrigation. This study implies that the incorporation of biochar with AWD irrigation should reduce water stress by enhancing soil moisture content aside from improving soil bulk density and porosity; besides this, it increases soil carbon and other nutrients, which helps with the increase of nutrient uptake for optimal rice yield, as well as improving water use efficiency. Nevertheless, regarding the water scarcity for agriculture and the rising demand for rice, making efficient use of biochar with AWD irrigation water may be the key to ensuring sustainable rice production for aclimate-resilient environment.

Author Contributions: Conceptualization, M.K.U. and M.F.S.; methodology, A.N.A.H.; formal analysis, A.N.A.H., A.A.A. and M.M.; investigation, M.K.U. and M.F.S.; data curation, A.M.A.; writing - original draft preparation, A.N.A.H.; writing-review and editing, M.H. and A.M.A.; supervision, M.K.U. All authors involved in this study helped in the writing and improvement of the paper. All authors have read and agreed to the published version of the manuscript.

Funding: This research was funded by National Agricultural Technology ProgramPhase-IIProject, Bangladesh Agricultural Research Council.

Institutional Review Board Statement: Not applicable.

Informed Consent Statement: Not applicable.

Data Availability Statement: The data presented in this study are available on request from the corresponding author. The data are not publicly available because it is a part of a PhD study.

Acknowledgments: The authors are grateful to the National Agricultural Technology Program Phase-II Project, Bangladesh Agricultural Research Council for the financial support and Universiti Putra Malaysia, Selangor Darul Ehsan, Malaysia for the research facilities.

Conflicts of Interest: The authors declare no conflict of interest. 


\section{Appendix A}

Table A1. Physicochemical properties of initial soil.

\begin{tabular}{cc}
\hline Parameter & Value \\
\hline \%Sand & 7.65 \\
$\%$ Silt & 29.81 \\
\%Clay & 62.54 \\
Textural class & Clay \\
$\mathrm{pH}$ & 5.14 \\
Cation exchange capacity $\left(\mathrm{cmol}_{\mathrm{c}} \cdot \mathrm{kg}^{-1}\right)$ & \\
Total carbon $(\%)$ & 5.36 \\
Total nitrogen $(\%)$ & 0.40 \\
Available $\left.\mathrm{P}(\mathrm{mg} \mathrm{kg})^{-1}\right)$ & 12.34 \\
Exchangeable K $\left(\mathrm{cmol}_{\mathrm{c}} \cdot \mathrm{kg}^{-1}\right)$ & 1.38 \\
Exchangeable Ca $\left(\mathrm{cmol}_{\mathrm{c}} \cdot \mathrm{kg}^{-1}\right)$ & 12.01 \\
Exchangeable $\mathrm{Mg}\left(\mathrm{cmol}_{\mathrm{c}} \cdot \mathrm{kg}^{-1}\right)$ & 7.71 \\
Total S $\left(\mathrm{mg} \mathrm{kg}^{-1}\right)$ & 1400 \\
$\%$ Moisture (at field capacity) & 28.14 \\
\hline
\end{tabular}

Table A2. Chemical characteristics of biochar and compost.

\begin{tabular}{cccccccccc}
\hline Organic Amendment & $\begin{array}{c}\mathbf{p H} \\
\text { Soil: } \mathbf{H}_{\mathbf{2}} \mathbf{O} \\
\mathbf{( 1 : 2 . 5 )}\end{array}$ & $\begin{array}{c}\mathbf{C E C} \\
\mathbf{( c m o l}_{\mathbf{c}} \cdot \mathbf{k g}^{-\mathbf{1}} \mathbf{)}\end{array}$ & $\mathbf{C}$ & $\mathbf{N}$ & $\mathbf{P}$ & $\mathbf{K}$ & $\mathbf{C a}$ & $\mathbf{M g}$ & $\mathbf{S}$ \\
$\mathbf{\%}$ & 7.12 & 50.42 & 24.86 & 0.38 & 0.31 & 0.75 & 0.17 & 0.17 & 0.15 \\
\hline Rice husk biochar & 8.50 & 58.32 & 52.11 & 1.13 & 0.19 & 5.08 & 0.71 & 0.39 & 0.15 \\
Oil plam empty fruit & 6.45 & 28.15 & 28.95 & 0.93 & 0.10 & 0.36 & 1.38 & 0.23 & 0.25 \\
bunch biochar & Compost & &
\end{tabular}

Table A3. Monthly average temperature and humidity during the experiment.

\begin{tabular}{cccc}
\hline \multirow{2}{*}{ Month } & \multicolumn{2}{c}{ Temperature $\left({ }^{\circ} \mathbf{C}\right)$} & Relative Humidity (\%) \\
\cline { 2 - 3 } & Maximum & Minimum & 80 \\
January & 32 & 21 & 79 \\
February & 33 & 22 & 77 \\
March & 33 & 22 & 81 \\
April & 34 & 23 & \\
\hline
\end{tabular}

\section{References}

1. Tumrani, S.A.; Pathan, P.A.; Suleman, B.M. Economic contribution of rice production and food security in Indonesia. Asia Pac. Res. J. 2015, 33, 63-74.

2. $\quad$ IRRI. Rice Knowledge Bank; IRRI: Los Baños, Philippines, 2018.

3. Bouman, B.A.M.; Lampayan, R.M.; Tuong, T.R. Water Management in Irrigated Rice. Coping with Water Scarcity; Hardy, B., Ed.; International Rice Research Institute (IRRI): Los Baños, Philippines, 2007.

4. Bouman, B.A.M. A conceptual framework for the improvement of crop water productivity at different spatial scales. Agric. Syst. 2007, 93, 43-60. [CrossRef]

5. Thakur, A.K.; Rath, S.; Patil, D.U.; Kumar, A. Effects on rice plant morphology and physiology of water and associated management practices of the system of rice intensification and their implications for crop performance. Paddy Water Environ. 2011, 9, 13-24. [CrossRef]

6. Pascual, V.J.; Wang, Y.-M. Utilizing rainfall and alternate wetting and drying irrigation for high water productivity in irrigated lowland paddy rice in southern Taiwan. Plant Prod. Sci. 2017, 20, 24-35. [CrossRef]

7. Lampayan, R.M.; Rejesus, R.M.; Singleton, G.R.; Bouman, B.A.M. Adoption and economics of alternate wetting and drying water management for irrigated lowland rice. Field Crop. Res. 2015, 170, 95-108. [CrossRef]

8. Belder, P.; Spiertz, J.H.J.; Bouman, B.A.M.; Lu, G.; Tuong, T.P. Nitrogen economy and water productivity of lowland rice under water-saving irrigation. Field Crop. Res. 2005, 93, 169-185. [CrossRef] 
9. Carrijo, D.R.; Lundy, M.E.; Linquist, B.A. Rice yields and water use under alternate wetting and drying irrigation: A meta-analysis. Field Crop. Res. 2017, 203, 173-180. [CrossRef]

10. Gordon, H.; Haygarth, P.M.; Bardgett, R.D. Drying and rewetting effects on soil microbial community composition and nutrient leaching. Soil Biol. Biochem. 2008, 40, 302-311. [CrossRef]

11. Feng, Z.; Leung, L.R.; Hagos, S.; Houze, R.A.; Burleyson, C.D.; Balaguru, K. More frequent intense and long-lived storms dominate the springtime trend in central US rainfall. Nat. Commun. 2016, 7, 13429. [CrossRef] [PubMed]

12. Solaiman, Z.M.; Anawar, H.M. Application of Biochars for Soil Constraints: Challenges and Solutions. Pedosphere 2015, 25, 631-638. [CrossRef]

13. Mosharrof, M.; Uddin, M.K.; Jusop, S.; Sulaiman, M.F.; Shamsuzzaman, S.M.; Haque, A.N.A. Integrated use of biochar and lime as a tool to improve maize yield and mitigate $\mathrm{CO}_{2}$ emission: A review. Chil. J. Agric. Res. 2021, 81, 109-118. [CrossRef]

14. Lehmann, J.; Stephen, J. Biochar for Environmental Management, 2nd ed.; Lehmann, J., Stephen, J., Eds.; Routledge: London, UK, 2015.

15. Blanco-Canqui, H. Does biochar improve all soil ecosystem services? GCB Bioenergy 2021, 13, 291-304. [CrossRef]

16. Mosharrof, M.; Uddin, M.K.; Sulaiman, M.F.; Mia, S.; Shamsuzzaman, S.M.; Haque, A.N.A. Combined Application of Biochar and Lime Increases Maize Yield and Accelerates Carbon Loss from an Acidic Soil. Agronomy 2021, 11, 1313. [CrossRef]

17. Solaiman, Z.M.; Shafi, M.I.; Beamont, E.; Anawar, H.M. Poultry Litter Biochar Increases Mycorrhizal Colonisation, Soil Fertility and Cucumber Yield in a Fertigation System on Sandy Soil. Agriculture 2020, 10, 480. [CrossRef]

18. Mosharrof, M.; Uddin, M.K.; Jusop, S.; Sulaiman, M.F.; Shamsuzzaman, S.M.; Haque, A.N.A. Changes in Acidic Soil Chemical Properties and Carbon Dioxide Emission Due to Biochar and Lime Treatments. Agriculture 2021, 11, 219. [CrossRef]

19. Głąb, T.; Palmowska, J.; Zaleski, T.; Gondek, K. Effect of biochar application on soil hydrological properties and physical quality of sandy soil. Geoderma 2016, 281, 11-20. [CrossRef]

20. Gamage, D.N.V.; Mapa, R.B.; Dharmakeerthi, R.S.; Biswas, A. Effect of rice-husk biochar on selected soil properties in tropical Alfisols. Soil Res. 2016, 54, 302. [CrossRef]

21. Haque, A.N.A.; Uddin, M.K.; Sulaiman, M.F.; Amin, A.M.; Hossain, M.; Solaiman, Z.M.; Mosharrof, M. Biochar with Alternate Wetting and Drying Irrigation: A Potential Technique for Paddy Soil Management. Agriculture 2021, 11, 367. [CrossRef]

22. Demir, Z.; Gülser, C. Effects of rice husk compost application on soil quality parameters in greenhouse conditions. Eurasian J. Soil Sci. 2015, 4, 185. [CrossRef]

23. Agegnehu, G.; VanBeek, C.; Bird, M.I. Influence of integrated soil fertility management in wheat and tef productivity and soil chemical properties in the highland tropical environment. J. Soil Sci. Plant Nutr. 2014, 14, 532-545. [CrossRef]

24. Kranz, C.N.; McLaughlin, R.A.; Johnson, A.; Miller, G.; Heitman, J.L. The effects of compost incorporation on soil physical properties in urban soils-A concise review. J. Environ. Manag. 2020, 261, 110209. [CrossRef]

25. Sohrabi, M.; Rafii, M.Y.; Hanafi, M.M.; Siti Nor Akmar, A.; Latif, M.A. Genetic Diversity of Upland Rice Germplasm in Malaysia Based on Quantitative Traits. Sci. World J. 2012, 2012, 1-9. [CrossRef] [PubMed]

26. Chan, C.S.; Zainudin, H.; Saad, A.R.; Azmi, M.A. Productive water use in aerobic rice cultivation. J. Trop. Agric. Food Sci. 2012, 40, 117-126.

27. Vaghefi, N.; Shamsudin, M.N.; Makmom, A.; Bagheri, M. The Economic Impacts of Climate Change on the Rice Production in Malaysia. Int. J. Agric. Res. 2010, 6, 67-74. [CrossRef]

28. Teh, C.B.S.; Talib, J.B. Soil Physics Analyses; Universiti Putra Malaysia Press: Serikembangan, Malaysia, 2006; ISBN 983-3455-64-6.

29. Benton, J.J. Laboratory Guide for Conducting Soil Tests and Plant Analysis; CRC Press: Boca Raton, FL, USA, 2001; ISBN 9780429132117.

30. Bray, R.H.; Kurtz, L.T. Determination of total, organic, and available forms of phosphorus in soils. Soil Sci. 1945, 59, 39-46. [CrossRef]

31. Schollenberger, C.J.; Simon, R.H. Determination of exchange capacity and exchangeable bases in soil-Ammonium acetate method. Soil Sci. 1945, 59, 13-24. [CrossRef]

32. Cottenie, A. Soil Testing and Plant Testing as a Basic Fertilizer Recommendation; FAO: Rome, Italy, 1980.

33. Farquhar, G.D.; Ehleringer, J.R.; Hubick, K.T. Carbon Isotope Discrimination and Photosynthesis. Annu. Rev. Plant Physiol. Plant Mol. Biol. 1989, 40, 503-537. [CrossRef]

34. Aldesuquy, H.; Baka, Z.; Mickky, B. Does exogenous application of kinetin and spermine mitigate the effect of seawater on yield attributes and biochemical aspects of grains. J. Stress Physiol. Biochem. 2013, 9, 21-34.

35. Blake, G.R. Particle density. In Encyclopedia of Soil Science; Chesworth, W., Ed.; Springer: Dordrecht, The Netherlands, 2008; pp. 504-505, ISBN 978-1-4020-3995-9.

36. Sharma, N.K.; Singh, R.J.; Kumar, K. Dry Matter Accumulation and Nutrient Uptake by Wheat (Triticum aestivum L.) under Poplar (Populus deltoides) Based Agroforestry System. ISRN Agron. 2012, 2012, 1-7. [CrossRef]

37. Ashraf, M.; Waheed, A. Screening of local/exotic accessions of lentil (Lens culinaris Medic.) for salt tolerance at two growth stages. Plant Soil 1990, 128, 167-176. [CrossRef]

38. Xu, Y.; Ge, J.; Tian, S.; Li, S.; Nguy-Robertson, A.L.; Zhan, M.; Cao, C. Effects of water-saving irrigation practices and drought resistant rice variety on greenhouse gas emissions from a no-till paddy in the central lowlands of China. Sci. Total Environ. 2015, 505, 1043-1052. [CrossRef] [PubMed]

39. Mohd, K.; Mohd, N.; Sarwar, J. Effects of Flooding and Alternate Wetting and Drying on the Yield Performance of Upland Rice. Pertanika Trop. Agric. Sci. 2016, 39, 299-309. 
40. Howell, K.R.; Shrestha, P.; Dodd, I.C. Alternate wetting and drying irrigation maintained rice yields despite half the irrigation volume, but is currently unlikely to be adopted by smallholder lowland rice farmers in Nepal. Food Energy Secur. 2015, 4, 144-157. [CrossRef]

41. Zhang, A.; Bian, R.; Pan, G.; Cui, L.; Hussain, Q.; Li, L.; Zheng, J.; Zheng, J.; Zhang, X.; Han, X.; et al. Effects of biochar amendment on soil quality, crop yield and greenhouse gas emission in a Chinese rice paddy: A field study of 2 consecutive rice growing cycles. Field Crop. Res. 2012, 127, 153-160. [CrossRef]

42. Maheshwari, D.K. Composting for Sustainable Agriculture; Sustainable Development and Biodiversity; Maheshwari, D.K., Ed.; Springer International Publishing: Cham, Switzerland, 2014; Volume 3, ISBN 978-3-319-08003-1.

43. Gao, T.; Gao, M.; Peng, J.; Li, N. Effects of Different Amount of Biochar on Nitrogen, Phosphorus and Potassium Nutrients in Soil. IOP Conf. Ser. Mater. Sci. Eng. 2018, 394, 022043. [CrossRef]

44. Haque, A.N.A.; Uddin, M.K.; Sulaiman, M.F.; Amin, A.M.; Hossain, M.; Zaibon, S.; Mosharrof, M. Assessing the Increase in Soil Moisture Storage Capacity and Nutrient Enhancement of Different Organic Amendments in Paddy Soil. Agriculture 2021, 11, 44. [CrossRef]

45. Batista, E.M.C.C.; Shultz, J.; Matos, T.T.S.; Fornari, M.R.; Ferreira, T.M.; Szpoganicz, B.; de Freitas, R.A.; Mangrich, A.S. Effect of surface and porosity of biochar on water holding capacity aiming indirectly at preservation of the Amazon biome. Sci. Rep. 2018, 8, 10677. [CrossRef]

46. Chen, L.; Liu, M.; Ali, A.; Zhou, Q.; Zhan, S.; Chen, Y.; Pan, X.; Zeng, Y. Effects of Biochar on Paddy Soil Fertility Under Different Water Management Modes. J. Soil Sci. Plant Nutr. 2020, 20, 1810-1818. [CrossRef]

47. Dong, D.; Feng, Q.; McGrouther, K.; Yang, M.; Wang, H.; Wu, W. Effects of biochar amendment on rice growth and nitrogen retention in a waterlogged paddy field. J. Soils Sediments 2015, 15, 153-162. [CrossRef]

48. Kameyama, K.; Miyamoto, T.; Iwata, Y.; Shiono, T. Effects of Biochar Produced From Sugarcane Bagasse at Different Pyrolysis Temperatures on Water Retention of a Calcaric Dark Red Soil. Soil Sci. 2016, 181, 20-28. [CrossRef]

49. Lambers, H.; Chapin, S.F., III; Pons, T.L. Plant Physiological Ecology, 2nd ed.; Springer: New York, NY, USA, 2008.

50. Javed, A.; Ashraf, M.Y.; Sabir, S.A.; Wajid, I. Use of carbon isotope discrimination technique to sustain rice productivity under stressed and low land irrigated ecosystem of Pakistan. Pak. J. Bot. 2012, 44, 85-93.

51. Centritto, M.; Lauteri, M.; Monteverdi, M.C.; Serraj, R. Leaf gas exchange, carbon isotope discrimination, and grain yield in contrasting rice genotypes subjected to water deficits during the reproductive stage. J. Exp. Bot. 2009, 60, 2325-2339. [CrossRef]

52. Yao, F.; Huang, J.; Cui, K.; Nie, L.; Xiang, J.; Liu, X.; Wu, W.; Chen, M.; Peng, S. Agronomic performance of high-yielding rice variety grown under alternate wetting and drying irrigation. Field Crop. Res. 2012, 126, 16-22. [CrossRef]

53. Haefele, S.M.; Konboon, Y.; Wongboon, W.; Amarante, S.; Maarifat, A.A.; Pfeiffer, E.M.; Knoblauch, C. Effects and fate of biochar from rice residues in rice-based systems. Field Crop. Res. 2011, 121, 430-440. [CrossRef]

54. Bakar, R.A.; Razak, Z.A.; Ahmad, S.H.; Seh-Bardan, B.J.; Tsong, L.C.; Meng, C.P. Influence of Oil Palm Empty Fruit Bunch Biochar on Floodwater $\mathrm{pH}$ and Yield Components of Rice Cultivated on Acid Sulphate Soil under Rice Intensification Practices. Plant Prod. Sci. 2015, 18, 491-500. [CrossRef]

55. Biederman, L.A.; Harpole, W.S. Biochar and its effects on plant productivity and nutrient cycling: A meta-analysis. GCB Bioenergy 2013, 5, 202-214. [CrossRef]

56. El-Naggar, A.; Lee, S.S.; Awad, Y.M.; Yang, X.; Ryu, C.; Rizwan, M.; Rinklebe, J.; Tsang, D.C.W.; Ok, Y.S. Influence of soil properties and feedstocks on biochar potential for carbon mineralization and improvement of infertile soils. Geoderma 2018, 332, 100-108. [CrossRef]

57. Fidel, R.B.; Laird, D.A.; Thompson, M.L.; Lawrinenko, M. Characterization and quantification of biochar alkalinity. Chemosphere 2017, 167, 367-373. [CrossRef]

58. Shi, R.; Li, J.; Ni, N.; Xu, R. Understanding the biochar's role in ameliorating soil acidity. J. Integr. Agric. 2019, 18, 1508-1517. [CrossRef]

59. Borken, W.; Matzner, E. Reappraisal of drying and wetting effects on C and N mineralization and fluxes in soils. Glob. Chang. Biol. 2009, 15, 808-824. [CrossRef]

60. Butterly, C.R.; McNeill, A.M.; Baldock, J.A.; Marschner, P. Rapid changes in carbon and phosphorus after rewetting of dry soil. Biol. Fertil. Soils 2011, 47, 41-50. [CrossRef]

61. Oliver, V.; Cochrane, N.; Magnusson, J.; Brachi, E.; Monaco, S.; Volante, A.; Courtois, B.; Vale, G.; Price, A.; Teh, Y.A. Effects of water management and cultivar on carbon dynamics, plant productivity and biomass allocation in European rice systems. Sci. Total Environ. 2019, 685, 1139-1151. [CrossRef] [PubMed]

62. Miyata, A.; Leuning, R.; Denmead, O.T.; Kim, J.; Harazono, Y. Carbon dioxide and methane fluxes from an intermittently flooded paddy field. Agric. For. Meteorol. 2000, 102, 287-303. [CrossRef]

63. Liu, Y.; Wan, K.; Tao, Y.; Li, Z.; Zhang, G.; Li, S.; Chen, F. Carbon Dioxide Flux from Rice Paddy Soils in Central China: Effects of Intermittent Flooding and Draining Cycles. PLoS ONE 2013, 8, e56562. [CrossRef]

64. Alberto, M.C.R.; Wassmann, R.; Buresh, R.J.; Quilty, J.R.; Correa, T.Q.; Sandro, J.M.; Centeno, C.A.R. Measuring methane flux from irrigated rice fields by eddy covariance method using open-path gas analyzer. Field Crop. Res. 2014, 160, 12-21. [CrossRef]

65. Wang, Y.; Liu, R. Improvement of acidic soil properties by biochar from fast pyrolysis. Environ. Prog. Sustain. Energy 2018, 37, 1743-1749. [CrossRef] 
66. Yang, S.; Chen, X.; Jiang, Z.; Ding, J.; Sun, X.; Xu, J. Effects of Biochar Application on Soil Organic Carbon Composition and Enzyme Activity in Paddy Soil under Water-Saving Irrigation. Int. J. Environ. Res. Public Health 2020, 17, 333. [CrossRef]

67. Tan, X.; Shao, D.; Liu, H.; Yang, F.; Xiao, C.; Yang, H. Effects of alternate wetting and drying irrigation on percolation and nitrogen leaching in paddy fields. Paddy Water Environ. 2013, 11, 381-395. [CrossRef]

68. Clough, T.; Condron, L.; Kammann, C.; Müller, C. A Review of Biochar and Soil Nitrogen Dynamics. Agronomy 2013, 3, $275-293$. [CrossRef]

69. Garg, K.K.; Das, B.S.; Safeeq, M.; Bhadoria, P.B.S. Measurement and modeling of soil water regime in a lowland paddy field showing preferential transport. Agric. Water Manag. 2009, 96, 1705-1714. [CrossRef]

70. Rawat, J.; Saxena, J.; Sanwal, P. Biochar: A Sustainable Approach for Improving Plant Growth and Soil Properties. In Biochar-An Imperative Amendment for Soil and the Environment; IntechOpen: London, UK, 2019.

71. Ahmad, M.; Lee, S.S.; Dou, X.; Mohan, D.; Sung, J.-K.; Yang, J.E.; Ok, Y.S. Effects of pyrolysis temperature on soybean stover- and peanut shell-derived biochar properties and TCE adsorption in water. Bioresour. Technol. 2012, 118, 536-544. [CrossRef] [PubMed]

72. Major, J.; Rondon, M.; Molina, D.; Riha, S.J.; Lehmann, J. Nutrient Leaching in a Colombian Savanna Oxisol Amended with Biochar. J. Environ. Qual. 2012, 41, 1076-1086. [CrossRef] [PubMed]

73. Luo, Y.; Jiao, Y.; Zhao, X.; Li, G.; Zhao, L.; Meng, H. Improvement to Maize Growth Caused by Biochars Derived From Six Feedstocks Prepared at Three Different Temperatures. J. Integr. Agric. 2014, 13, 533-540. [CrossRef]

74. Wang, Y.; Yin, R.; Liu, R. Characterization of biochar from fast pyrolysis and its effect on chemical properties of the tea garden soil. J. Anal. Appl. Pyrolysis 2014, 110, 375-381. [CrossRef]

75. Dokoohaki, H.; Miguez, F.E.; Laird, D.; Horton, R.; Basso, A.S. Assessing the Biochar Effects on Selected Physical Properties of a Sandy Soil: An Analytical Approach. Commun. Soil Sci. Plant Anal. 2017, 48, 1387-1398. [CrossRef]

76. Sun, F.; Lu, S. Biochars improve aggregate stability, water retention, and pore-space properties of clayey soil. J. Plant Nutr. Soil Sci. 2014, 177, 26-33. [CrossRef] 